\title{
Characterization of the first vaginal Lactobacillus crispatus genomes isolated in Brazil
}

\author{
Marcelle Oliveira de Almeida ${ }^{1}$, Rodrigo Carvalho ${ }^{1}$, Flavia Figueira Aburjaile ${ }^{1}$, Fabio Malcher Miranda ${ }^{1}$, Janaína \\ Canário Cerqueira ${ }^{1}$, Bertram Brenig ${ }^{2}$, Preetam Ghosh ${ }^{3}$, Rommel Ramos ${ }^{4}$, Rodrigo B Kato ${ }^{5}$, Siomar de Castro \\ Soares $^{6}$, Artur Silva ${ }^{4}$, Vasco Azevedo ${ }^{\text {Corresp., }}{ }^{\text {, Marcus Vinicius Canário Viana }}{ }^{1}$ \\ ${ }^{1}$ Department of Genetics, Ecology, and Evolution, Federal University of Minas Gerais, Belo Horizonte, Minas Gerais, Brazil \\ 2 Institute of Veterinary Medicine, University of Göttingen, Göttingen, Germany \\ 3 Department of Computer Science, Virginia Commonwealth University, Richmond, Virginia, United States \\ 4 Department of Genetics, Federal University of Pará, Belém, Pará, Brazil \\ 5 Post-graduation Program in Bioinformatics, Federal University of Minas Gerais, Belo Horizonte, Minas Gerais, Brazil \\ 6 Department of Immunology, Microbiology, and Parasitology, Federal University of Triângulo Mineiro, Uberaba, Minas Gerais, Brazil \\ Corresponding Author: Vasco Azevedo \\ Email address: vascoariston@gmail.com
}

Background. Lactobacillus crispatus is the dominant species in the vaginal microbiota associated with health and considered a homeostasis biomarker. Interestingly, some strains are even used as probiotics. However, the genetic mechanisms of $L$. crispatus involved in the control of the vaginal microbiome and protection against bacterial vaginosis (BV) are not entirely known. To further investigate these mechanisms, we sequenced and characterized the first four $L$. crispatus genomes from vaginal samples from Brazilian women and used genome-wide association study (GWAS) and comparative analyses to identify genetic mechanisms involved in healthy or BV conditions and selective pressures acting in the vaginal microbiome.

Methods. The four genomes were sequenced, assembled using ten different strategies and automatically annotated. The functional characterization was performed by bioinformatics tools comparing with known probiotic strains. Moreover, it was selected one representative strain (L. crispatus CRI4) for in vitro detection of phages by electron microscopy. Evolutionary analysis, including phylogeny, GWAS and positive selection were performed using 46 public genomes strains representing health and BV conditions.

Results. Genes involved in probiotic effects such as lactic acid production, hydrogen peroxide, bacteriocins, and adhesin were identified. Three hemolysins and putrescine production were predicted, although these features are also present in other probiotic strains. The four genomes presented no plasmids, but 14 known families insertion sequences and several prophages were detected. However, none of the mobile genetic elements contained antimicrobial resistance genes. The genomes harbor a CRISPR-Cas subtype II-A system that is probably inactivated due to fragmentation of the genes csn2 and cas9. No genomic feature was associated with a health condition, perhaps due to its multifactorial characteristic. Five genes were identified as under positive selection, but the selective pressure remains to be discovered. In conclusion, the Brazilian strains investigated in this study present potential protective properties, although in vitro and in vivo studies are required to confirm their efficacy and safety to be considered for human use. 


\section{Characterization of the first vaginal Lactobacillus}

2 crispatus genomes isolated in Brazil

3

4

5

6

7

8

Marcelle Oliveira de Almeida ${ }^{1}$, Rodrigo Carvalho ${ }^{1}$, Flavia Figueira Aburjaile ${ }^{1}$, Fabio Miranda ${ }^{1}$, Janaína Canário Cerqueira ${ }^{1}$, Bertram Brenig ${ }^{2}$, Preetam Ghosh ${ }^{3}$, Rommel Ramos ${ }^{4}$, Rodrigo

Bentes Kato ${ }^{1}$, Siomar de Castro Soares ${ }^{5}$, Artur Silva ${ }^{4}$, Vasco Azevedo ${ }^{1}$, Marcus Vinicius Canário Viana $^{1,4}$

${ }^{1}$ Department of Genetics, Ecology, and Evolution, Federal University of Minas Gerais, Belo Horizonte, Minas Gerais, Brazil

${ }^{2}$ Institute of Veterinary Medicine, University of Göttingen, Göttingen, Germany

${ }^{3}$ Department of Computer Science, Virginia Commonwealth University, Richmond, Virginia, USA

${ }^{4}$ Department of Genetics, Federal University of Pará, Belém, Pará, Brazil

${ }^{5}$ Department of Immunology, Microbiology, and Parasitology, Federal University of Triângulo Mineiro, Uberaba, Minas Gerais, Brazil

Corresponding Author:

Vasco Azevedo ${ }^{1}$

Av. Presidente Antônio Carlos 6627, Belo Horizonte, Minas Gerais, 31270-901, Brazil

Email address: vasco@icb.ufmg.br

\section{Abstract}

Background. Lactobacillus crispatus is the dominant species in the vaginal microbiota associated with health and considered a homeostasis biomarker. Interestingly, some strains are even used as probiotics. However, the genetic mechanisms of L. crispatus involved in the control of the vaginal microbiome and protection against bacterial vaginosis (BV) are not entirely known. To further investigate these mechanisms, we sequenced and characterized the first four L. crispatus genomes from vaginal samples from Brazilian women and used genome-wide association study (GWAS) and comparative analyses to identify genetic mechanisms involved in healthy or BV conditions and selective pressures acting in the vaginal microbiome.

Methods. The four genomes were sequenced, assembled using ten different strategies and automatically annotated. The functional characterization was performed by bioinformatics tools comparing with known probiotic strains. Moreover, it was selected one representative strain $(L$. crispatus CRI4) for in vitro detection of phages by electron microscopy. Evolutionary analysis, including phylogeny, GWAS and positive selection were performed using 46 public genomes strains representing health and BV conditions.

Results. Genes involved in probiotic effects such as lactic acid production, hydrogen peroxide, bacteriocins, and adhesin were identified. Three hemolysins and putrescine production were 
40 predicted, although these features are also present in other probiotic strains. The four genomes presented no plasmids, but 14 known families insertion sequences and several prophages were detected. However, none of the mobile genetic elements contained antimicrobial resistance genes. The genomes harbor a CRISPR-Cas subtype II-A system that is probably inactivated due to fragmentation of the genes $\operatorname{csn} 2$ and $\operatorname{cas} 9$. No genomic feature was associated with a health condition, perhaps due to its multifactorial characteristic. Five genes were identified as under positive selection, but the selective pressure remains to be discovered. In conclusion, the Brazilian strains investigated in this study present potential protective properties, although in vitro and in vivo studies are required to confirm their efficacy and safety to be considered for human use.

\section{Introduction}

The vaginal microbiota of reproductive-age women is classified into at least five types called community state types (CST). Four of them are dominated by Lactobacillus crispatus (CST-I), L. gasseri (CST-II), L. iners (CST-III), or L. jensenii (CST-V). The CST-IV is characterized as having a significantly lower number of lactobacilli and an increased number and diversity of strict and facultative anaerobes (Ravel et al., 2011). The lactobacilli use the glycogen supplied by the host as a carbon source and create a protective environment against infections or colonization by pathogens and non-indigenous microbes by the production of L- and/or D-lactic acid, bacteriocins, hydrogen peroxide, competition for tissue adhesion, enhancement of the protective mucus layer integrity and modulation of the innate immune system response (Ravel et al., 2011; Smith \& Ravel, 2017).

CST-IV and III increase the risk of bacterial vaginosis (BV) due to L. iners being less effective in controlling the vaginal microbiota. BV is a condition characterized by a microbiota similar to CST-IV, vaginal $\mathrm{pH}>4.5$ and production of amino acid compounds, sometimes associated with clinical symptoms including discharge, fishy odor, and presence of clue cells. These conditions damage the host defenses and favor the development of opportunistic microorganisms that behave like pathogens (Smith \& Ravel, 2017; Barrientos-Durán et al., 2020). BV can be asymptomatic or associated with gynecological and obstetric complications, besides increasing the risk of sexually transmitted infections (Barrientos-Durán et al., 2020).

CST-I, dominated by L. crispatus, is most associated with vaginal health. This species is considered a biomarker of a healthy microbiota, and some strains are used as a probiotic to treat $\mathrm{BV}$. Its effect as a probiotic is not entirely clear, but it is believed to involve competitive exclusion strategies (Almeida et al., 2019). It was shown to outcompete Gardinerella vaginallis for tissue adhesion in vitro (Ojala et al., 2014) and, as other lactobacilli, inhibit the growth of pathogens in vivo by the production of lactic acid, but not hydrogen peroxide (Tachedjian, O'Hanlon \& Ravel, 2018). The decrease in L. crispatus is associated with BV, but the causes are not well understood. The differences in persistence and protection among strains is probably 
79 influenced by genetic differences that, if described, could be applied in the screening of more 80 efficient probiotic strains (Almeida et al., 2019).

81 Comparative genomic analyses have been performed to identify genomic features of $L$. 82 crispatus associated with female urogenital tract using samples from North America, Europe and 83 Asia (Ojala et al., 2014; Abdelmaksoud et al., 2016; France, Mendes-Soares \& Forney, 2016; 84 van der Veer et al., 2019; Pan, Hidalgo-Cantabrana \& Barrangou, 2020; Petit \& Read, 2020; 85 Zhang et al., 2020). Analyses that searched for genomic features associated with lactobacilli86 dominated (healthy) or BV microbiota were performed using samples isolated from the USA 87 (Abdelmaksoud et al., 2016) and Netherlands (van der Veer et al., 2019). Those studies point out mechanisms related to persistence during $\mathrm{BV}$, such as phase variation, rather than protection against this infirmity (van der Veer et al., 2019). In Latin America, although L. crispatus has been previously studied in Brazil as vaginal isolates (Branco et al., 2010) or as part of the vaginal microbiota (Martinez et al., 2008; Marconi et al., 2020), no complete genome has been sequenced, analyzed, and deposited in GenBank.

In this study, we characterize the first $L$. crispatus genomes isolated in Brazil from 93

\section{Materials \& Methods}

\section{Genome sequencing, assembly, and annotation}

In a previous study, vaginal fluid samples were collected from individuals diagnosed as healthy or with BV, with the approval of the ethics committee in research (COEP) of the Federal University of Minas Gerais (protocols ETIC 062/03 and 212/07) (Branco et al., 2010). L. crispatus strains were identified by cellular morphology (Gram-positive bacilli or coccobacilli), biochemistry test (catalase-negative) and 16S-23S rRNA restriction profiling (Branco et al., 2010). The genomes of strains CRI4, CRI8, CRI10 and CRI17 isolated from four healthy patients were sequenced using HiSeq 2500 (Illumina, San Diego, CA, USA) with paired-end libraries of $2 \times 150 \mathrm{bp}$. The sequencing reads quality was examined using FastQC v0.11.8 (Andrews, 2015). The sequencing reads were mapped to the genomes of 46 L. crispatus vaginal isolates to filter out contaminants (Table 1) using bowtie v2 (Langmead \& Salzberg, 2012), and the mapped reads were extracted using Samtools v1.7-2 (Li et al., 2009).

113 (Bankevich et al., 2012) (assembly 1), Unicycler v0.4.5 (Wick et al., 2017) with SPAdes v3.14.0 114 (2), ABySS v2.0 (Simpson et al., 2009) (3), MaSuRCA v3.4.0 (Zimin et al., 2013) (4) and an in

115 house pipeline (https://github.com/engbiopct/assembly-hiseq) that generates six other assemblies 116 (5 to 10). In the in-house pipeline, six strategies combine different software. The best k-mer 117 values were identified using KmerStream v1.1 (Melsted \& Halldórsson, 2014). Adapters were

118 removed using AdapterRemoval v2.3.1 (Schubert, Lindgreen \& Orlando, 2016). The genome 
119 assemblers were Edena v3.131028 (Hernandez et al., 2008) and SPAdes v3.13.0 (Bankevich et

120 al., 2012). The six assembly strategies were: Edena (5), KmerStream and SPAdes (6),

121 KmerStream and SPAdes, using Edena assembly as trusted contigs (7), AdapterRemoval,

122 KmerStream and SPAdes (8), reads processed by AdapterRemoval and the raw reads as input,

123 KmerStream, and SPAdes, using Edena assembly as trusted contigs (9), and AdapterRemoval,

124 KmerStream, and SPAdes, using Edena assembly as trusted contigs (10).

125 The best assembly for each genome was determined using QUAST v5.0.2 (Gurevich et

126 al., 2013). Then, the genome's paired-read sequencing data was used for scaffolding with

127 SSPACE v3.0 (Boetzer et al., 2011) and contig extension and gap filling with GapFiller v1.1.1

128 (Boetzer \& Pirovano, 2012). Finally, more gaps were closed using contigs from the other nine

129 assemblies and the chromosome of L. crispatus strain AB70 (CP026503.1) (Chang et al., 2019)

130 as a reference, using GFinisher (Guizelini et al., 2016). The presence of plasmids was

131 investigated using PlasmidFinder 2.1 (Carattoli et al., 2014). The four genomes were identified

132 from the species L. crispatus using the Type (Strain) Genome Server (Meier-Kolthoff \& Göker,

133 2019). The assemblies completeness was evaluated using BUSCO v4.0.6 (Seppey, Manni \&

134 Zdobnov, 2019), based on the presence of 402 single-copy orthologous genes shared within

135 Lactobacillales. The genomes were annotated using Prokka v1.11 (Seemann, 2014). The

136 GenBank accession numbers of the genomes from strains CRI4, CRI8, CRI10 and CRI17,

137 isolated from healthy patients, are JABERN01, JABERO01, JABERP01 and JABERQ01,

138 respectively (Table 2). Type Strain Genome Server (Meier-Kolthoff \& Göker, 2019) was used to

139 confirm the taxonomic classification of the 50 samples as L. crispatus strains.

140

141

\section{Criteria of public genomes selection}

142

143

We included in the analysis genomes available in public databases using the following

144 criteria: (i) vaginal isolate, (ii) the metadata explicitly informs the health condition of the individual, and/or the microbiome classification. A total of 46 samples were classified as belonging to "healthy" (26) or "BV" (20) condition groups and were used in previous studies (Hemmerling et al., 2010; Ojala et al., 2014; Abramov et al., 2014; Abdelmaksoud et al., 2016; Eslami et al., 2016; Dols et al., 2016; Chang et al., 2019; Clabaut et al., 2019, 2020; van der Veer et al., 2019). Table 1 shows the genomes list, including the microbiome classification, when available, and the terms in metadata used to classify the sample.

\section{Probiotic features}

152

Bacteriocins and linear azol(in)e-containing peptides (LAPs) were predicted using BAGEL4 (van Heel et al., 2018). The enzymes involved in the production of L- and D-lactate and hydrogen peroxide were identified using KEGG Mapper/BlastKOALA, under the pyruvate metabolism pathway. Adhesins were predicted using eggNOG-mapper v2 (Huerta-Cepas et al.,

156 2017). Protein IDs were identified using BLASTp (Camacho et al., 2009) using the GenBank non-redundant (nr) database, selecting hits with 100\% identity and coverage. Pathways involved 
158 in the biosynthesis of antimicrobial drugs with clinical importance (Chokesajjawatee et al., 2020)

159 were predicted using KEGG Mapper.

160

161

Safety assessment of the strains for probiotic applications

162

Detection of plasmids, insertion sequences, prophages, and CRISPR-Cas elements was

163 performed using PlasmidFinder (Carattoli et al., 2014), ISEScan (Xie \& Tang, 2017), PHASTER (Arndt et al., 2016), and CRISPRCasFinder (https://crisprcas.i2bc.parissaclay.fr/CrisprCasFinder/Index), respectively. The domains of the identified Cas proteins were predicted using InterProScan (Jones et al., 2014) and NCBI's Conserved Domain Database (Lu et al., 2020). Multiple alignments of sequences of interest were performed using the Clustal Omega web service (Larkin et al., 2007). Local alignment of sequences of interest across genomes was performed using BLASTn (Camacho et al., 2009) implemented in PATRIC (Davis et al., 2020).

Virulence factor genes were detected using the databases VFDB (Liu et al., 2019) and Ecoli_VF (https://github.com/phac-nml/ecoli_vf), while antimicrobial resistance genes were detected using the databases ARG-ANNOT (Gupta et al., 2014), CARD (Alcock et al., 2020), MEGARes (Doster et al., 2019), NCBI AMRFinderPlus (Feldgarden et al., 2019) and ResFinder (Bortolaia et al., 2020). The screening using these databases was performed using ABRicate (https://github.com/tseemann/abricate) with default parameters.

The presence of the toxins hemolysins, enzymes involved in the synthesis of biogenic amines and other undesirable genes, as listed by Chokesajjawatee et al. (Chokesajjawatee et al., 2020), were manually screened using KEGG Mapper (Kanehisa \& Sato, 2020) implemented in

181 BlastKOALA v2.2 (Kanehisa, Sato \& Morishima, 2016).

183

One representative strain (L. crispatus CRI4) was subjected to the induction of lysogenic the culture was initially inoculated in $5 \mathrm{~mL}$ of Man-Rogosa-Sharpe (MRS) medium. The optical density (OD) was measured until reaching $\mathrm{DO}_{600}=0.2$. Then, $0.4 \mu \mathrm{g} / \mathrm{mL}$ of Mitomycin $\mathrm{C}$ (Sigma) was added in the culture and incubated at $37^{\circ} \mathrm{C}$ overnight. Afterward, the supernatant was collected and filtered in sterile $0.22 \mu \mathrm{m}$ membrane. A $10 \mu \mathrm{L}$ sample of the filtered lysate was applied to a 200 mesh grid at the UFMG electron microscopy center (CM-UFMG) and visualization was performed in Tecnai G2-12 Transmission Electron Microscope, SpiritBiotwin FEI, 120kV.

192

\section{Comparative analyses using public genomes}

194

We performed comparative analysis including the for strains from Brazil and 46 public 
197 presence/absence and features of interest, and detection of positive selection in protein-coding 198 genes.

For phylogenomic analysis, L. helveticus DSM20075 genome (GenBank accession

200

201

202

203

204

205

206

207

208

209

210

211

212

213

214

215

216

217

218

219

220

221

222

223

224

225

226

227

228

229

230

231

232

233

234

235

ACLM01) was used as an outgroup, the conserved genes across all 51 genomes were estimated by Roary v3.6.0, and their nucleotide sequences were aligned using MAFFT (Katoh et al., 2005) implemented in Roary. The alignment was used as input for IQ-Tree v1.6.12 (Nguyen et al., 2015) for phylogenetic inference using the Maximum Likelihood. The confidence values were estimated using 1,000 rounds of bootstrapping. The tree was edited using iTOL (Letunic \& Bork, 2019).

We tested the associations of gene presence/absence with a health condition and geographical locations suggested by the phylogenetic tree. A GWAS based on gene presence/absence was performed using Scoary v1.6.16 (Brynildsrud et al., 2016). Scoary estimates association by pairwise comparisons on a phylogeny (Maddison, 2000) to correct population structure and permutation. The input was a gene presence-absence matrix from the 50 L. crispatus genomes estimated using Roary and a phylogenetic tree generated by IQ-Tree v1.6.12, utilizing the core gene alignment calculated by Roary, and a matrix containing the presence-absence of the features across the samples.

A genome-scale positive selection analysis was performed using POTION v1.1.2 (Hongo et al., 2015). To generate the input, FastOrtho (https://github.com/PATRIC3/FastOrtho) was used to identify ortholog groups across the $50 \mathrm{~L}$. crispatus genomes. The file containing the orthologous group's information and multifasta files containing nucleotide sequences of proteincoding genes were used as input for POTION v1.1.2. The genome-scale positive selection analysis used site tests with the models M1 and M2, and M7 and M8 (Yang \& Nielsen, 2002). The POTION configuration file is available as Data S1. The function of the identified proteins was annotated using eggNOG-mapper (Huerta-Cepas et al., 2017), the subcellular localization using SufG+ v1.2.1 (Barinov et al., 2009), and the GenBank protein ID using BLASTp (Agarwala et al., 2016).

\section{Results}

\section{Genome sequencing and taxonomy}

The four sequenced genomes were assembled as drafts, and no plasmid was found. Table 2 shows the statistics of genome assembly and annotation. The genomes completeness ranged from 99 to $99.5 \%$, while the reference strain AB70, available as a complete genome sequenced using PacBio RS II platform (Chang et al., 2019), had its completeness estimated as $99 \%$. The four sequenced genomes and the 46 public genomes were classified as L. crispatus by TYGS, with $\mathrm{dDDH}>70 \%$ and $\mathrm{G}+\mathrm{C}$ content divergence of less than $1 \%$ to the strain JCM $1185^{\mathrm{T}}$ (Data S2).

\section{Probiotic features}


236

237

238

239

240

241

242

243

244

245

246

247

248

249

250

251

252

253

254

255

256

257

258

259

260

261

262

263

264

265

266

267

268

269

270

271

272

273

274

275

Features associated with probiotic effects in the four strains from Brazil are shown in Table 3. We identified genes involved in the biosynthesis of D-lactate (1), L-lactate (3), hydrogen peroxide (1), bacteriocins (9), LAPs (1) and adhesins (10, five classes) across the four genomes. No pathway for biosynthesis of antimicrobial drugs of clinical importance was found.

\section{Safety assessment of the strains for probiotic applications}

Features associated with safety in the four strains from Brazil are shown in Table 4. About mobile elements, no plasmid was predicted, as previously stated. 131 to 184 IS from 14 known families were identified in the four genomes, and one new family was predicted across CRI8 (2 copies), CRI10 (2) and CRI17 (1) (Data S3). The new IS has a size of 2,088 bp and harbors two genes coding a site-specific integrase-resolvase (IS607-like family, GenBank protein ID WP_005728427.1) and a transposase (IS605 family, AZR15009.1) (Data S4). The multiple alignments of the five copies show the IS is fragmented in the contig 44 of strain CRI10, and the difference among the complete sequences is a SNP (T to $\mathrm{G}$ ) in position 1,350 (Data S5). A BLASTn against the four strains from Brazil and other 123 public $L$ crispatus genomes database identified hits with $\geq 99 \%$ identity and $\geq 98 \%$ coverage with 42 genomes from strains isolated from the female human urogenital tract, 39 of them public genomes (Data S3).

Five or six prophages were predicted across the four genomes, classified as questionable (score 70-90) or incomplete (score $<70$ ), with most of them close to contig ends. In strains CRI8 and CRI17, some of the predicted prophages harbored the new IS (Fig. 1 and Data S6). We identified CRISPR-Cas systems subtype II-A in the four strains and subtype II-C only in strain CRI10 (Table 4, Data S7). A closer examination of the subtype II-A system reveals that all four genomes contain CRISPR loci and Cas proteins-encoding genes cns2, cas2, cas 1 , and cas 9 . However, a transposase is inserted in $\operatorname{csn} 2$ in each strain, resulting in two gene fragments. The gene cas 9 is also fragmented in all strains, with a transposase inserted between fragments in strains CRI4 and CRI8. CRI17 has an extra copy of cas 9 . The subtype II-C system is represented in CRI10 by a single cas 9 gene (Fig. 2). All the cas 9 CDSs lack one or more domains.

No virulence or antimicrobial resistance gene was predicted using ABRicate. With the search for virulence and undesirable genes using KEGG Mapper/BlastKOALA, we identified two hemolysins ( $t l y C$ and $h l y I I)$ ), one bile salt hydrolase $(c b h)$, and one enzyme involved in the biosynthesis of putrescine (Ornithine decarboxylase, odcl). Manual screening of Prokka annotation showed a third hemolysin, Hemolysin A. The search for toxin biosynthesis identified an "Ornithine decarboxylase" (odcl) (WP_005727730.1) involved in the synthesis of the biogenic amine putrescine, in all for strains.

\section{In vitro detection of phages}

Several rod-shaped particles of varying length and thickness were observed by electron microscopy, some of them similar to Myoviridae bacteriophages. This pattern was repeated throughout the slide (Fig. 3). 
276 Comparative analyses using public genomes

277

278

279

280

281

282

283

284

285

286

287

288

289

290

291

292

293

294

295

296

297

298

299

300

301

302

303

304

305

306

307

308

309

310

311

312

313

314

315

The strains did not cluster according to a health condition. However, strains from Brazil were the closest to strains from the Netherlands, even in different clusters (Fig. 4). The GWAS based on gene presence/absence implemented in Scoary did not identify an association with a health condition $(p>0.05)$. Due to the clustering of strains from Brazil and the Netherlands, we tested the association with these two geographical locations and the result was also negative. A total of 8 protein-coding genes were identified as under positive selection $(q<0.05)$. After manual curation for false positives caused by alignment artifacts, five genes were obtained: a surface exposed "S-layer protein precursor," three phage related proteins, and a hypothetical protein (Table 5, Data S8).

\section{Discussion}

In the first four $L$. crispatus sequenced genomes from Brazil, we identified genes involved in the protective properties of vaginal lactobacilli (Smith \& Ravel, 2017) such as the production of lactic acid, bacteriocins, hydrogen peroxide and adhesion (Table 3).

For safety reasons, a probiotic strain should not present features associated with virulence and antimicrobial resistance, as well as mobile elements that could transfer those features to other microorganisms from the host microbiome (Pariza et al., 2015; Chokesajjawatee et al., 2020). No antimicrobial resistance gene was found, and only three hemolysins were predicted as virulence factors, which have also been previously identified in other Lactobacillus probiotic strains (Zafar \& Saier, 2020) (Table 4). The hemolysin-III is widespread across Lactobacillus species, including strains considered as safe and commercially available (Chokesajjawatee et al., 2020). This result implies these genes should not be a safety concern. However, the hemolytic activity of those proteins from Lactobacillus must be verified in further studies. We predicted the synthesis of the toxic biogenic amine putrescine by the ornithine decarboxylase pathway in all four strains (Table 4). This is one of the pathways in which the decarboxylation of amino acids and organic acids generates a proton motive force that can regulate intracellular $\mathrm{pH}$ (acidic stress response) and generate ATP (Romano et al., 2014; Del Rio et al., 2018). The production of biogenic amines is an important safety issue when screening probiotic strains as they may cause intoxication when consumed in high concentrations (García-Villar, Hernández-Cassou \& Saurina, 2009; Linares et al., 2011).

Concerning mobile elements, as expected for probiotic strains, no plasmids were found. Despite of numerous ISs from 14 known families (Table 4 and Data S3) and one from a new family-specific of vaginal isolates (Data S3, Data S4, and Data S5), none of them were associated with antibiotic resistance genes.

Four to six incomplete prophages across the genomes were revealed (Table 4 and Data S6). Some incomplete prophages could be the result of an assembly artifact, as the genomes were assembled as drafts and most prophages were located close to a contig end. The possible role of the newly described IS, and the associated prophages in the genome evolution (Siguier, 
316 Gourbeyre \& Chandler, 2014) or adaptation to the urogenital niche should be investigated.

317 Moreover, the presence of complete phages was confirmed by electron microscopy in CRI4

318 lysate after Mitomycin C induction (Fig. 3). Therefore, our results suggest the possibility of

319 lysogeny of this strain.

320 The presence of a functional CRISPR-Cas system could prevent the infection by

321 bacteriophages (Crawley et al., 2018) that could influence the vaginal microbiota (Macklaim et

322 al., 2013). We detected the subtype II-A in the four genomes and II-C in CRI10 (Table 4, Data

323 S7). However, all csn 2 and cas 9 genes across the genomes are fragmented (Fig. 2), lacking one

324 or more domains. Also, the subtype II-C in CRI10 is probably a prediction artifact, as a single

325 subtype with two sets of cas genes can be detected as multiple subtypes (Crawley et al., 2018)

326 and only the subtypes I-B, I-E, and II-A were reported for this species (Petit \& Read, 2020). The

327 result suggests that the CRISPR-Cas systems are not functional due to gene fragmentation which

328 could compromise the prevention of phage infections.

329 In the phylogenomic tree, health-related condition does not show clustering (Fig. 4), a

330 result also found in other studies (Abdelmaksoud et al., 2016; Pan, Hidalgo-Cantabrana \&

331 Barrangou, 2020). However, Brazil-Netherlands clusters were formed. The GWAS performed

332 using Scoary did not find gene presence/absence associated with the health condition or the

333 Brazil-Netherlands clusters. This result is different from a previous study, which has shown an

334 association of transposases and a glycosyltransferase being more abundant in BV strains (van der

335 Veer et al., 2019). The differences obtained between association studies could be due to the

336 multifactorial characteristic of BV (Barrientos-Durán et al., 2020; Marconi et al., 2020).

337 The positive selection analysis identified five genes (Table 5, Data S8). The S-layer

338 precursor has the surface layer A protein (SLAP) domain described in $s l p B$ from L. acidophilus

339 ATCC 4356 (Boot, Kolen \& Pouwels, 1995). S-layer proteins form symmetric, porous, lattice-

340 like layers that cover the cell surface with poorly known functions that can involve mediation of

341 bacterial adherence to host cells, extracellular matrix proteins, or protective or enzymatic

342 functions (Hynönen \& Palva, 2013). Surface exposed proteins are located in the interface with

343 the environment and can be under positive selection due to interaction with several factors such

344 as antimicrobial compounds, viruses, hosts, and other bacteria (Petersen et al., 2007). The three

345 phage related proteins have domains for DNA biding, integration, and recombination. The

346 selective pressures acting in those proteins have yet to be identified.

\section{Conclusions}

350

351

The first $L$. crispatus genomes from vaginal isolates from Brazil presented several genes associated with probiotic characteristics. Although mobile genetic elements were detected, they

352

353

354 do not present antimicrobial resistance genes that could be transmitted to other bacteria. For safety issues, the functionality of the hemolysin related genes must be further experimentally confirmed. No genomic feature was associated with healthy and BV conditions, and the positive 
355

356

357

358

359

360

361

362

363

364

365

366

367

368

369

370

371

372

373

374

375

376

377

378

379

380

381

382

383

384

385

386

387

388

389

390

391

392

393

394

selection was predicted in an S-layer protein and phage related genes but have yet to be investigated.

\section{References}

Abdelmaksoud AA, Koparde VN, Sheth NU, Serrano MG, Glascock AL, Fettweis JM, Strauss JF, Buck GA, Jefferson KK. 2016. Comparison of Lactobacillus crispatus isolates from Lactobacillus-dominated vaginal microbiomes with isolates from microbiomes containing bacterial vaginosis-associated bacteria. Microbiology (United Kingdom) 162:466-475. DOI: 10.1099/mic.0.000238.

Abramov V, Khlebnikov V, Kosarev I, Bairamova G, Vasilenko R, Suzina N, Machulin A, Sakulin V, Kulikova N, Vasilenko N, Karlyshev A, Uversky V, Chikindas ML, Melnikov V. 2014. Probiotic Properties of Lactobacillus crispatus 2,029: Homeostatic Interaction with Cervicovaginal Epithelial Cells and Antagonistic Activity to Genitourinary Pathogens. Probiotics and Antimicrobial Proteins 6:165-176. DOI: 10.1007/s12602-014-9164-4.

Agarwala R, Barrett T, Beck J, Benson DA, Bollin C, Bolton E, Bourexis D, Brister JR, Bryant SH, Canese K, Charowhas C, Clark K, Dicuccio M, Dondoshansky I, Federhen S, Feolo M, Funk K, Geer LY, Gorelenkov V, Hoeppner M, Holmes B, Johnson M, Khotomlianski V, Kimchi A, Kimelman M, Kitts P, Klimke W, Krasnov S, Kuznetsov A, Landrum MJ, Landsman D, Lee JM, Lipman DJ, Lu Z, Madden TL, Madej T, Marchler-Bauer A, KarschMizrachi I, Murphy T, Orris R, Ostell J, O'sullivan C, Panchenko A, Phan L, Preuss D, Pruitt KD, Rodarmer K, Rubinstein W, Sayers E, Schneider V, Schuler GD, Sherry ST, Sirotkin K, Siyan K, Slotta D, Soboleva A, Soussov V, Starchenko G, Tatusova TA, Todorov K, Trawick BW, Vakatov D, Wang Y, Ward M, Wilbur WJ, Yaschenko E, Zbicz K. 2016. Database resources of the National Center for Biotechnology Information. Nucleic Acids Research 44:D7-D19. DOI: 10.1093/nar/gkv1290.

Alcock BP, Raphenya AR, Lau TTY, Tsang KK, Bouchard M, Edalatmand A, Huynh W, Nguyen AL V., Cheng AA, Liu S, Min SY, Miroshnichenko A, Tran HK, Werfalli RE, Nasir JA, Oloni M, Speicher DJ, Florescu A, Singh B, Faltyn M, Hernandez-Koutoucheva A, Sharma AN, Bordeleau E, Pawlowski AC, Zubyk HL, Dooley D, Griffiths E, Maguire F, Winsor GL, Beiko RG, Brinkman FSL, Hsiao WWL, Domselaar G V., McArthur AG. 2020. CARD 2020: antibiotic resistome surveillance with the comprehensive antibiotic resistance database. Nucleic acids research 48:D517-D525. DOI: 10.1093/nar/gkz935.

Almeida MO, Carmo FLR do, Gala-García A, Kato R, Gomide AC, Drummond RMN, Drumond MM, Agresti PM, Barh D, Brening B, Ghosh P, Silva A, Azevedo V, Viana MVC. 2019. Lactobacillus crispatus protects against bacterial vaginosis. Genetics and Molecular Research 18. DOI: $10.4238 / \mathrm{gmr} 18475$.

Andrews S. 2015.FASTQC A Quality Control tool for High Throughput Sequence Data. Available at http://www.bioinformatics.babraham.ac.uk/projects/fastqc/Help/3 Analysis Modules/ 
395

396

397

398

399

400

401

402

403

404

405

406

407

408

409

410

411

412

413

414

415

416

417

418

419

420

421

422

423

424

425

426

427

428

429

430

431

432

433

434

Arndt D, Grant JR, Marcu A, Sajed T, Pon A, Liang Y, Wishart DS. 2016. PHASTER: a better, faster version of the PHAST phage search tool. Nucleic acids research 44:W16-W21. DOI: 10.1093/nar/gkw387.

Bankevich A, Nurk S, Antipov D, Gurevich AA, Dvorkin M, Kulikov AS, Lesin VM, Nikolenko SI, Pham S, Prjibelski AD, Pyshkin A V., Sirotkin A V., Vyahhi N, Tesler G, Alekseyev MA, Pevzner PA. 2012. SPAdes: A new genome assembly algorithm and its applications to single-cell sequencing. Journal of Computational Biology 19:455-477. DOI: $10.1089 / \mathrm{cmb} .2012 .0021$.

Barinov A, Loux V, Hammani A, Nicolas P, Langella P, Ehrlichh D, Maguin E, Van Guchte M De. 2009. Prediction of surface exposed proteins in Streptococcus pyogenes, with a potential application to other Gram-positive bacteria. Proteomics 9:61-73. DOI: 10.1002/pmic.200800195.

Barrientos-Durán A, Fuentes-López A, de Salazar A, Plaza-Díaz J, García F. 2020. Reviewing the composition of vaginal microbiota: Inclusion of nutrition and probiotic factors in the maintenance of eubiosis. Nutrients 12:1-30. DOI: 10.3390/nu12020419.

Boetzer M, Henkel C V., Jansen HJ, Butler D, Pirovano W. 2011. Scaffolding pre-assembled contigs using SSPACE. Bioinformatics 27:578-579. DOI: 10.1093/bioinformatics/btq683.

Boetzer M, Pirovano W. 2012. Toward almost closed genomes with GapFiller. Genome Biology 13:R56. DOI: $10.1186 / \mathrm{gb}-2012-13-6-\mathrm{r} 56$.

Boot HJ, Kolen CPAM, Pouwels PH. 1995. Identification, cloning, and nucleotide sequence of a silent S-layer protein gene of Lactobacillus acidophilus ATCC 4356 which has extensive similarity with the S-layer protein gene of this species. Journal of Bacteriology 177:72227230. DOI: $10.1128 / \mathrm{jb} .177 .24 .7222-7230.1995$.

Bortolaia V, Kaas RS, Ruppe E, Roberts MC, Schwarz S, Cattoir V, Philippon A, Allesoe RL, Rebelo AR, Florensa AF, Fagelhauer L, Chakraborty T, Neumann B, Werner G, Bender JK, Stingl K, Nguyen M, Coppens J, Xavier BB, Malhotra-Kumar S, Westh H, Pinholt M, Anjum MF, Duggett NA, Kempf I, Nykäsenoja S, Olkkola S, Wieczorek K, Amaro A, Clemente L, Mossong J, Losch S, Ragimbeau C, Lund O, Aarestrup FM. 2020. ResFinder 4.0 for predictions of phenotypes from genotypes. Journal of Antimicrobial Chemotherapy. DOI: $10.1093 / \mathrm{jac} / \mathrm{dkaa} 345$.

Branco KMGR, Nardi RMD, Moreira JLS, Nunes AC, Farias LM, Nicoli JR, Carvalho MAR. 2010. Identification and in vitro production of Lactobacillus antagonists from women with or without bacterial vaginosis. Brazilian Journal of Medical and Biological Research 43:338-344. DOI: 10.1590/S0100-879X2010007500013.

Brynildsrud O, Bohlin J, Scheffer L, Eldholm V. 2016. Rapid scoring of genes in microbial pangenome-wide association studies with Scoary. Genome Biology:1-9. DOI: 10.1186/s13059016-1108-8.

Camacho C, Coulouris G, Avagyan V, Ma N, Papadopoulos J, Bealer K, Madden TL. 2009. BLAST plus: architecture and applications. BMC Bioinformatics 10:1. DOI: Artn $421 \mathrm{hnDoi}$ 10.1186/1471-2105-10-421. 
435 Carattoli A, Zankari E, García-Fernández A, Voldby Larsen M, Lund O, Villa L, Møller

436

437

438

439

440

441

442

443

444

445

446

447

448

449

450

451

452

453

454

455

456

457

458

459

460

461

462

463

464

465

466

467

468

469

470

471

472

473

474 Aarestrup F, Hasman H. 2014. In Silico Detection and Typing of Plasmids using PlasmidFinder and Plasmid Multilocus Sequence Typing. Antimicrobial Agents and Chemotherapy 58:3895-3903. DOI: 10.1128/AAC.02412-14.

Chang D-H, Rhee M-S, Lee S-K, Chung I-H, Jeong H, Kim B-C. 2019. Complete Genome Sequence of Lactobacillus crispatus AB70, Isolated from a Vaginal Swab from a Healthy Pregnant Korean Woman. Microbiology Resource Announcements 8. DOI: 10.1128/MRA.01736-18.

Chokesajjawatee N, Santiyanont P, Chantarasakha K, Kocharin K, Thammarongtham C, Lertampaiporn S, Vorapreeda T, Srisuk T, Wongsurawat T, Jenjaroenpun P, Nookaew I, Visessanguan W. 2020. Safety Assessment of a Nham Starter Culture Lactobacillus plantarum BCC9546 via Whole-genome Analysis. Scientific Reports 10:1-12. DOI: 10.1038/s41598-020-66857-2.

Clabaut M, Boukerb AM, Racine P, Pichon C, Kremser C, Picot J, Karsybayeva M, Redziniak G, Chevalier S, Feuilloley MGJ. 2020. Draft Genome Sequence of Lactobacillus crispatus CIP 104459, Isolated from a Vaginal Swab. Microbiology Resource Announcements 9:1819. DOI: 10.1128/MRA.01373-19.

Clabaut M, Boukerb AM, Racine P-J, Pichon C, Kremser C, Queiroz A, Karsybayeva M, Redziniak G, Chevalier S, Feuilloley MGJ. 2019. Draft Genome Sequence of Lactobacillus crispatus Strain V4, Isolated from a Vaginal Swab from a Young Healthy Nonmenopausal Woman. Microbiology Resource Announcements 8:1-2. DOI: 10.1128/MRA.00856-19.

Crawley AB, Henriksen ED, Stout E, Brandt K, Barrangou R. 2018. Characterizing the activity of abundant, diverse and active CRISPR-Cas systems in lactobacilli. Scientific Reports 8:112. DOI: $10.1038 / \mathrm{s} 41598-018-29746-3$.

Davis JJ, Wattam AR, Aziz RK, Brettin T, Butler RRM, Butler RRM, Chlenski P, Conrad N, Dickerman A, Dietrich EM, Gabbard JL, Gerdes S, Guard A, Kenyon RW, Machi D, Mao C, Murphy-Olson D, Nguyen M, Nordberg EK, Olsen GJ, Olson RD, Overbeek JC, Overbeek R, Parrello B, Pusch GD, Shukla M, Thomas C, VanOeffelen M, Vonstein V, Warren AS, Xia F, Xie D, Yoo H, Stevens R. 2020. The PATRIC Bioinformatics Resource Center: Expanding data and analysis capabilities. Nucleic Acids Research 48:D606-D612. DOI: $10.1093 / \mathrm{nar} / \mathrm{gkz} 943$.

Dols JAM, Molenaar D, van der Helm JJ, Caspers MPM, de Kat Angelino-Bart A, Schuren FHJ, Speksnijder AGCL, Westerhoff H V., Richardus JH, Boon ME, Reid G, de Vries HJC, Kort R. 2016. Molecular assessment of bacterial vaginosis by Lactobacillus abundance and species diversity. BMC Infectious Diseases 16:180. DOI: 10.1186/s12879-016-1513-3.

Doster E, Lakin SM, Dean CJ, Wolfe C, Young JG, Boucher C, Belk KE, Noyes NR, Morley PS. 2019. MEGARes 2.0: a database for classification of antimicrobial drug, biocide and metal resistance determinants in metagenomic sequence data. Nucleic Acids Research. DOI: 10.1093/nar/gkz1010.

Eslami S, Hadjati J, Motevaseli E, Mirzaei R, Farashi Bonab S, Ansaripour B, Khoramizadeh

Peer) reviewing PDF | (2020:11:55691:1:1:NEW 16 Feb 2021) 
475

476

477

478

479

480

481

482

483

484

485

486

487

488

489

490

491

492

493

494

495

496

497

498

499

500

501

502

503

504

505

506

507

508

509

510

511

512

513

514

MR. 2016. Lactobacillus crispatus strain SJ-3C-US induces human dendritic cells (DCs) maturation and confers an anti-inflammatory phenotype to DCs. APMIS 124:697-710. DOI: 10.1111/apm.12556.

Feldgarden M, Brover V, Haft DH, Prasad AB, Slotta DJ, Tolstoy I, Tyson GH, Zhao S, Hsu CH, McDermott PF, Tadesse DA, Morales C, Simmons M, Tillman G, Wasilenko J, Folster JP, Klimke W. 2019. Validating the AMRFinder Tool and Resistance Gene Database by Using Antimicrobial Resistance Genotype-Phenotype Correlations in a Collection of Isolates. Antimicrobial Agents and Chemotherapy 63. DOI: 10.1128/AAC.00483-19.

France MT, Mendes-Soares H, Forney LJ. 2016. Genomic comparisons of Lactobacillus crispatus and Lactobacillus iners reveal potential ecological drivers of community composition in the vagina. Applied and Environmental Microbiology 82:7063-7073. DOI: 10.1128/AEM.02385-16.

García-Villar N, Hernández-Cassou S, Saurina J. 2009. Determination of biogenic amines in wines by pre-column derivatization and high-performance liquid chromatography coupled to mass spectrometry. Journal of Chromatography A 1216:6387-6393. DOI: 10.1016/j.chroma.2009.07.029.

Guizelini D, Raittz RT, Cruz LM, Souza EM, Steffens MBR, Pedrosa FO. 2016. GFinisher: a new strategy to refine and finish bacterial genome assemblies. Scientific Reports 6:34963. DOI: $10.1038 /$ srep34963.

Gupta SK, Padmanabhan BR, Diene SM, Lopez-Rojas R, Kempf M, Landraud L, Rolain JM. 2014. ARG-annot, a new bioinformatic tool to discover antibiotic resistance genes in bacterial genomes. Antimicrobial Agents and Chemotherapy 58:212-220. DOI: 10.1128/AAC.01310-13.

Gurevich A, Saveliev V, Vyahhi N, Tesler G. 2013. QUAST: Quality assessment tool for genome assemblies. Bioinformatics 29:1072-1075. DOI: 10.1093/bioinformatics/btt086.

van Heel AJ, de Jong A, Song C, Viel JH, Kok J, Kuipers OP. 2018. BAGEL4: a user-friendly web server to thoroughly mine RiPPs and bacteriocins. Nucleic Acids Research 46:W278W281. DOI: 10.1093/nar/gky383.

Hemmerling A, Harrison W, Schroeder A, Park J, Korn A, Shiboski S, Foster-Rosales A, Cohen CR. 2010. Phase 2a study assessing colonization efficiency, safety, and acceptability of Lactobacillus crispatus CTV-05 in women with bacterial vaginosis. Sexually Transmitted Diseases 37:745-750. DOI: 10.1097/OLQ.0b013e3181e50026.

Hernandez D, Francois P, Farinelli L, Osteras M, Schrenzel J. 2008. De novo bacterial genome sequencing: Millions of very short reads assembled on a desktop computer. Genome Research 18:802-809. DOI: 10.1101/gr.072033.107.

Hongo JA, de Castro GM, Cintra LC, Zerlotini A, Lobo FP. 2015. POTION: an end-to-end pipeline for positive Darwinian selection detection in genome-scale data through phylogenetic comparison of protein-coding genes. BMC genomics 16:567. DOI: 10.1186/s12864-015-1765-0.

Huerta-Cepas J, Forslund K, Coelho LP, Szklarczyk D, Jensen LJ, Von Mering C, Bork P. 2017. 
515

516

517

518

519

520

521

522

523

524

525

526

527

528

529

530

531

532

533

534

535

536

537

538

539

540

541

542

543

544

545

546

547

548

549

550

551

552

553

554

Fast genome-wide functional annotation through orthology assignment by eggNOGmapper. Molecular Biology and Evolution 34:2115-2122. DOI: 10.1093/molbev/msx148.

Hynönen U, Palva A. 2013. Lactobacillus surface layer proteins: Structure, function and applications. Applied Microbiology and Biotechnology 97:5225-5243. DOI: 10.1007/s00253-013-4962-2.

Jones P, Binns D, Chang H-Y, Fraser M, Li W, McAnulla C, McWilliam H, Maslen J, Mitchell A, Nuka G, Pesseat S, Quinn AF, Sangrador-Vegas A, Scheremetjew M, Yong S-Y, Lopez R, Hunter S. 2014. InterProScan 5: genome-scale protein function classification. Bioinformatics 30:1236-1240. DOI: 10.1093/bioinformatics/btu031.

Kanehisa M, Sato Y. 2020. KEGG Mapper for inferring cellular functions from protein sequences. Protein Science 29:28-35. DOI: 10.1002/pro.3711.

Kanehisa M, Sato Y, Morishima K. 2016. BlastKOALA and GhostKOALA: KEGG Tools for Functional Characterization of Genome and Metagenome Sequences. Journal of Molecular Biology 428:726-731. DOI: 10.1016/j.jmb.2015.11.006.

Katoh K, Kuma KI, Toh H, Miyata T. 2005. MAFFT version 5: Improvement in accuracy of multiple sequence alignment. Nucleic Acids Research 33:511-518. DOI: 10.1093/nar/gki198.

Kiliç AO, Pavlova SI, Ma WG, Tao L. 1996. Analysis of Lactobacillus phages and bacteriocins in American dairy products and characterization of a phage isolated from yogurt. Applied and environmental microbiology 62:2111-2116. DOI: 10.1128/AEM.62.6.2111-2116.1996.

Langmead B, Salzberg SL. 2012. Fast gapped-read alignment with Bowtie 2. Nature Methods 9:357-359. DOI: 10.1038/nmeth.1923.

Larkin MA, Blackshields G, Brown NP, Chenna R, Mcgettigan PA, McWilliam H, Valentin F, Wallace IM, Wilm A, Lopez R, Thompson JD, Gibson TJ, Higgins DG. 2007. Clustal W and Clustal X version 2.0. Bioinformatics 23:2947-2948. DOI: 10.1093/bioinformatics/btm404.

Letunic I, Bork P. 2019. Interactive Tree Of Life (iTOL) v4: recent updates and new developments. Nucleic Acids Research 47:W256-W259. DOI: 10.1093/nar/gkz239.

Li H, Handsaker B, Wysoker A, Fennell T, Ruan J, Homer N, Marth G, Abecasis G, Durbin R. 2009. The Sequence Alignment/Map format and SAMtools. Bioinformatics 25:2078-2079. DOI: 10.1093/bioinformatics/btp352.

Linares DM, Martín MC, Ladero V, Alvarez MA, Fernández M. 2011. Biogenic amines in dairy products. Critical Reviews in Food Science and Nutrition 51:691-703. DOI: 10.1080/10408398.2011.582813.

Liu B, Zheng D, Jin Q, Chen L, Yang J. 2019. VFDB 2019: a comparative pathogenomic platform with an interactive web interface. Nucleic Acids Research 47:D687-D692. DOI: 10.1093/nar/gky1080.

Lu S, Wang J, Chitsaz F, Derbyshire MK, Geer RC, Gonzales NR, Gwadz M, Hurwitz DI, Marchler GH, Song JS, Thanki N, Yamashita RA, Yang M, Zhang D, Zheng C, Lanczycki CJ, Marchler-Bauer A. 2020. CDD/SPARCLE: the conserved domain database in 2020.

Peer) reviewing PDF | (2020:11:55691:1:1:NEW 16 Feb 2021) 
555

556

557

558

559

560

561

562

563

564

565

566

567

568

569

570

571

572

573

574

575

576

577

578

579

580

581

582

583

584

585

586

587

588

589

590

591

592

593

594

Nucleic Acids Research 48:D265-D268. DOI: 10.1093/nar/gkz991.

Macklaim JM, Fernandes AD, Di Bella JM, Hammond JA, Reid G, Gloor GB. 2013. Comparative meta-RNA-seq of the vaginal microbiota and differential expression by Lactobacillus iners in health and dysbiosis. Microbiome 1:1-11. DOI: 10.1186/2049-2618$1-12$.

Maddison WP. 2000. Testing character correlation using pairwise comparisons on a phylogeny. Journal of Theoretical Biology 202:195-204. DOI: 10.1006/jtbi.1999.1050.

Marconi C, El-Zein M, Ravel J, Ma B, Lima MD, Carvalho NS, Alves RRF, Parada CMGL, Leite SHM, Giraldo PC, Gonçalves AK, Franco EL, Silva MG. 2020. Characterization of the vaginal microbiome in women of reproductive age from 5 Regions in Brazil. Sexually Transmitted Diseases 47:562-569. DOI: 10.1097/OLQ.0000000000001204.

Martinez RCR, Franceschini SA, Patta MC, Quintana SM, Nunes ÁC, Moreira JLS, Anukam KC, Reid G, De Martinis ECP. 2008. Analysis of vaginal lactobacilli from healthy and infected Brazilian women. Applied and Environmental Microbiology 74:4539-4542. DOI: 10.1128/AEM.00284-08.

Meier-Kolthoff JP, Göker M. 2019. TYGS is an automated high-throughput platform for stateof-the-art genome-based taxonomy. Nature Communications 10:2182. DOI: 10.1038/s41467-019-10210-3.

Melsted P, Halldórsson B V. 2014. KmerStream: streaming algorithms for k-mer abundance estimation. Bioinformatics 30:3541-3547. DOI: 10.1093/bioinformatics/btu713.

Nguyen L-T, Schmidt HA, von Haeseler A, Minh BQ. 2015. IQ-TREE: A Fast and Effective Stochastic Algorithm for Estimating Maximum-Likelihood Phylogenies. Molecular Biology and Evolution 32:268-274. DOI: 10.1093/molbev/msu300.

Ojala T, Kankainen M, Castro J, Cerca N, Edelman S, Westerlund-Wikström B, Paulin L, Holm L, Auvinen P. 2014. Comparative genomics of Lactobacillus crispatus suggests novel mechanisms for the competitive exclusion of Gardnerella vaginalis. BMC Genomics 15:121. DOI: $10.1186 / 1471-2164-15-1070$.

Pan M, Hidalgo-Cantabrana C, Barrangou R. 2020. Host and body site-specific adaptation of Lactobacillus crispatus genomes. NAR Genomics and Bioinformatics 2:1-14. DOI: 10.1093/nargab/lqaa001.

Pariza MW, Gillies KO, Kraak-Ripple SF, Leyer G, Smith AB. 2015. Determining the safety of microbial cultures for consumption by humans and animals. Regulatory Toxicology and Pharmacology 73:164-171. DOI: 10.1016/j.yrtph.2015.07.003.

Petersen L, Bollback JP, Dimmic M, Hubisz M, Nielsen R. 2007. Genes under positive selection in Escherichia coli. Genome Research 17:1336-1343. DOI: 10.1101/gr.6254707.

Petit RA, Read TD. 2020. Bactopia: a flexible pipeline for complete analysis of bacterial genomes. bioRxiv:2020.02.28.969394. DOI: 10.1101/2020.02.28.969394.

Ravel J, Gajer P, Abdo Z, Schneider GM, Koenig SSK, McCulle SL, Karlebach S, Gorle R, Russell J, Tacket CO, Brotman RM, Davis CC, Ault K, Peralta L, Forney LJ. 2011. Vaginal microbiome of reproductive-age women. Proceedings of the National Academy of Sciences 
595

596

597

598

599

600

601

602

603

604

605

606

607

608

609

610

611

612

613

614

615

616

617

618

619

620

621

622

623

624

625

626

627

628

629

630

631

632

633

634

108:4680-4687. DOI: 10.1073/pnas.1002611107.

Raya RR, H'bert EM. 2009. Isolation of Phage via Induction of Lysogens. In: Clokie MRJ, Kropinski A eds. Bacteriophages Methods and Protocols, Volume 1: Isolation, Characterization, and Interactions. New York: Humana Press, 23-32. DOI: 10.1007/978-160327-164-6_3.

Del Rio B, Alvarez-Sieiro P, Redruello B, Martin MC, Fernandez M, Ladero V, Alvarez MA. 2018. Lactobacillus rossiae strain isolated from sourdough produces putrescine from arginine article. Scientific Reports 8:1-10. DOI: 10.1038/s41598-018-22309-6.

Romano A, Ladero V, Alvarez MA, Lucas PM. 2014. Putrescine production via the ornithine decarboxylation pathway improves the acid stress survival of Lactobacillus brevis and is part of a horizontally transferred acid resistance locus. International Journal of Food Microbiology 175:14-19. DOI: 10.1016/j.ijfoodmicro.2014.01.009.

Schubert M, Lindgreen S, Orlando L. 2016. AdapterRemoval v2: rapid adapter trimming, identification, and read merging. BMC Research Notes 9:88. DOI: 10.1186/s13104-0161900-2.

Seemann T. 2014. Prokka: rapid prokaryotic genome annotation. Bioinformatics 30:2068-2069. DOI: 10.1093/bioinformatics/btu153.

Seppey M, Manni M, Zdobnov EM. 2019. BUSCO: Assessing Genome Assembly and Annotation Completeness. In: Martin Kollmar ed. Gene Prediction. New York, NY: Humana Press, 227-245. DOI: 10.1007/978-1-4939-9173-0_14.

Siguier P, Gourbeyre E, Chandler M. 2014. Bacterial insertion sequences: Their genomic impact and diversity. FEMS Microbiology Reviews 38:865-891. DOI: 10.1111/1574-6976.12067.

Simpson JT, Wong K, Jackman SD, Schein JE, Jones SJM, Birol I. 2009. ABySS: A parallel assembler for short read sequence data. Genome Research 19:1117-1123. DOI: 10.1101/gr.089532.108.

Smith SB, Ravel J. 2017. The vaginal microbiota, host defence and reproductive physiology. Journal of Physiology 595:451-463. DOI: 10.1113/JP271694.

Tachedjian G, O'Hanlon DE, Ravel J. 2018. The implausible "in vivo" role of hydrogen peroxide as an antimicrobial factor produced by vaginal microbiota. Microbiome 6:3-7. DOI: 10.1186/s40168-018-0418-3.

van der Veer C, Hertzberger RY, Bruisten SM, Tytgat HLP, Swanenburg J, de Kat AngelinoBart A, Schuren F, Molenaar D, Reid G, de Vries H, Kort R. 2019. Comparative genomics of human Lactobacillus crispatus isolates reveals genes for glycosylation and glycogen degradation: implications for in vivo dominance of the vaginal microbiota. Microbiome 7:49. DOI: 10.1186/s40168-019-0667-9.

Wick RR, Judd LM, Gorrie CL, Holt KE. 2017. Unicycler: Resolving bacterial genome assemblies from short and long sequencing reads. PLOS Computational Biology 13:e1005595. DOI: 10.1371/journal.pcbi.1005595.

Xie Z, Tang H. 2017. ISEScan: automated identification of insertion sequence elements in prokaryotic genomes. Bioinformatics 33:3340-3347. DOI: 10.1093/bioinformatics/btx433. 
635 Yang Z, Nielsen R. 2002. Codon-Substitution Models for Detecting Molecular Adaptation at

636

637

638

639

640

641

642

643

644

645

646

647

648

649

650

651

652

653

654

655

656

657

658

659

660

661

662

663

664

665

666

667

668

669

670

671

672

673

674 Individual Sites Along Specific Lineages. Molecular Biology and Evolution 19:908-917. DOI: 10.1093/oxfordjournals.molbev.a004148.

Zafar H, Saier MH. 2020. Comparative Genomics of the Transport Proteins of Ten Lactobacillus Strains. Genes 11:1234. DOI: 10.3390/genes11101234.

Zhang Q, Zhang L, Ross P, Zhao J, Zhang H, Chen W. 2020. Comparative Genomics of Lactobacillus crispatus from the Gut and Vagina Reveals Genetic Diversity and Lifestyle Adaptation. Genes 11:360. DOI: 10.3390/genes11040360.

Zimin A V, Marçais G, Puiu D, Roberts M, Salzberg SL, Yorke JA. 2013. The MaSuRCA genome assembler. Bioinformatics 29:2669-2677. DOI: 10.1093/bioinformatics/btt476.

Alcock BP, Raphenya AR, Lau TTY, Tsang KK, Bouchard M, Edalatmand A, Huynh W, Nguyen AL V., Cheng AA, Liu S, Min SY, Miroshnichenko A, Tran HK, Werfalli RE, Nasir JA, Oloni M, Speicher DJ, Florescu A, Singh B, Faltyn M, Hernandez-Koutoucheva A, Sharma AN, Bordeleau E, Pawlowski AC, Zubyk HL, Dooley D, Griffiths E, Maguire F, Winsor GL, Beiko RG, Brinkman FSL, Hsiao WWL, Domselaar G V., McArthur AG. 2020. CARD 2020: antibiotic resistome surveillance with the comprehensive antibiotic resistance database. Nucleic acids research 48:D517-D525. DOI: 10.1093/nar/gkz935.

Almeida MO, Carmo FLR do, Gala-García A, Kato R, Gomide AC, Drummond RMN, Drumond MM, Agresti PM, Barh D, Brening B, Ghosh P, Silva A, Azevedo V, Viana MVC. 2019. Lactobacillus crispatus protects against bacterial vaginosis. Genetics and Molecular Research 18. DOI: 10.4238/gmr18475.

Andrews S. 2015.FASTQC A Quality Control tool for High Throughput Sequence Data. Available at http://www.bioinformatics.babraham.ac.uk/projects/fastqc/Help/3 Analysis Modules/

Arndt D, Grant JR, Marcu A, Sajed T, Pon A, Liang Y, Wishart DS. 2016. PHASTER: a better, faster version of the PHAST phage search tool. Nucleic acids research 44:W16-W21. DOI: 10.1093/nar/gkw387.

Bankevich A, Nurk S, Antipov D, Gurevich AA, Dvorkin M, Kulikov AS, Lesin VM, Nikolenko SI, Pham S, Prjibelski AD, Pyshkin A V., Sirotkin A V., Vyahhi N, Tesler G, Alekseyev MA, Pevzner PA. 2012. SPAdes: A new genome assembly algorithm and its applications to single-cell sequencing. Journal of Computational Biology 19:455-477. DOI: 10.1089/cmb.2012.0021.

Barrientos-Durán A, Fuentes-López A, de Salazar A, Plaza-Díaz J, García F. 2020. Reviewing the composition of vaginal microbiota: Inclusion of nutrition and probiotic factors in the maintenance of eubiosis. Nutrients 12:1-30. DOI: 10.3390/nu12020419.

Boetzer M, Henkel C V., Jansen HJ, Butler D, Pirovano W. 2011. Scaffolding pre-assembled contigs using SSPACE. Bioinformatics 27:578-579. DOI: 10.1093/bioinformatics/btq683.

Boetzer M, Pirovano W. 2012. Toward almost closed genomes with GapFiller. Genome Biology 13:R56. DOI: 10.1186/gb-2012-13-6-r56.

Boot HJ, Kolen CPAM, Pouwels PH. 1995. Identification, cloning, and nucleotide sequence of a

Peer) reviewing PDF | (2020:11:55691:1:1:NEW 16 Feb 2021) 
675

676

677

678

679

680

681

682

683

684

685

686

687

688

689

690

691

692

693

694

695

696

697

698

699

700

701

702

703

704

705

706

707

708

709

710

711

712

713

714

silent S-layer protein gene of Lactobacillus acidophilus ATCC 4356 which has extensive similarity with the S-layer protein gene of this species. Journal of Bacteriology 177:72227230. DOI: $10.1128 / \mathrm{jb} .177 .24 .7222-7230.1995$.

Bortolaia V, Kaas RS, Ruppe E, Roberts MC, Schwarz S, Cattoir V, Philippon A, Allesoe RL, Rebelo AR, Florensa AF, Fagelhauer L, Chakraborty T, Neumann B, Werner G, Bender JK, Stingl K, Nguyen M, Coppens J, Xavier BB, Malhotra-Kumar S, Westh H, Pinholt M, Anjum MF, Duggett NA, Kempf I, Nykäsenoja S, Olkkola S, Wieczorek K, Amaro A, Clemente L, Mossong J, Losch S, Ragimbeau C, Lund O, Aarestrup FM. 2020. ResFinder 4.0 for predictions of phenotypes from genotypes. Journal of Antimicrobial Chemotherapy. DOI: $10.1093 / \mathrm{jac} / \mathrm{dkaa345.}$

Branco KMGR, Nardi RMD, Moreira JLS, Nunes AC, Farias LM, Nicoli JR, Carvalho MAR. 2010. Identification and in vitro production of Lactobacillus antagonists from women with or without bacterial vaginosis. Brazilian Journal of Medical and Biological Research 43:338-344. DOI: 10.1590/S0100-879X2010007500013.

Brynildsrud O, Bohlin J, Scheffer L, Eldholm V. 2016. Rapid scoring of genes in microbial pangenome-wide association studies with Scoary. Genome Biology:1-9. DOI: 10.1186/s13059016-1108-8.

Camacho C, Coulouris G, Avagyan V, Ma N, Papadopoulos J, Bealer K, Madden TL. 2009. BLAST plus: architecture and applications. BMC Bioinformatics 10:1. DOI: Artn $421 \mathrm{hnDoi}$ 10.1186/1471-2105-10-421.

Carattoli A, Zankari E, García-Fernández A, Voldby Larsen M, Lund O, Villa L, Møller Aarestrup F, Hasman H. 2014. In Silico Detection and Typing of Plasmids using PlasmidFinder and Plasmid Multilocus Sequence Typing. Antimicrobial Agents and Chemotherapy 58:3895-3903. DOI: 10.1128/AAC.02412-14.

Carvalho FP de. 2011. Perfil Microbiológico de Mulheres com e sem Candidíase Vaginal com Ênfase em Lactobacillus spp. e Candida spp.: Identificação Molecular, Atividade Antagonista e Susceptibilidade a Drogas Antifúngicas. Universidade Federal de Minas Gerais.

Chang D-H, Rhee M-S, Lee S-K, Chung I-H, Jeong H, Kim B-C. 2019. Complete Genome Sequence of Lactobacillus crispatus AB70, Isolated from a Vaginal Swab from a Healthy Pregnant Korean Woman. Microbiology Resource Announcements 8. DOI: 10.1128/MRA.01736-18.

Chokesajjawatee N, Santiyanont P, Chantarasakha K, Kocharin K, Thammarongtham C, Lertampaiporn S, Vorapreeda T, Srisuk T, Wongsurawat T, Jenjaroenpun P, Nookaew I, Visessanguan W. 2020. Safety Assessment of a Nham Starter Culture Lactobacillus plantarum BCC9546 via Whole-genome Analysis. Scientific Reports 10:1-12. DOI: 10.1038/s41598-020-66857-2.

Crawley AB, Henriksen ED, Stout E, Brandt K, Barrangou R. 2018. Characterizing the activity of abundant, diverse and active CRISPR-Cas systems in lactobacilli. Scientific Reports 8:112. DOI: $10.1038 / \mathrm{s} 41598-018-29746-3$.

Peer) reviewing PDF | (2020:11:55691:1:1:NEW 16 Feb 2021) 
715 Davis JJ, Wattam AR, Aziz RK, Brettin T, Butler RRM, Butler RRM, Chlenski P, Conrad N, 716 Dickerman A, Dietrich EM, Gabbard JL, Gerdes S, Guard A, Kenyon RW, Machi D, Mao

717

718

719

720

721

722

723

724

725

726

727

728

729

730

731

732

733

734

735

736

737

738

739

740

741

742

743

744

745

746

747

748

749

750

751

752

753

754

C, Murphy-Olson D, Nguyen M, Nordberg EK, Olsen GJ, Olson RD, Overbeek JC, Overbeek R, Parrello B, Pusch GD, Shukla M, Thomas C, VanOeffelen M, Vonstein V, Warren AS, Xia F, Xie D, Yoo H, Stevens R. 2020. The PATRIC Bioinformatics Resource Center: Expanding data and analysis capabilities. Nucleic Acids Research 48:D606-D612. DOI: $10.1093 /$ nar/gkz943.

Doster E, Lakin SM, Dean CJ, Wolfe C, Young JG, Boucher C, Belk KE, Noyes NR, Morley PS. 2019. MEGARes 2.0: a database for classification of antimicrobial drug, biocide and metal resistance determinants in metagenomic sequence data. Nucleic Acids Research. DOI: 10.1093/nar/gkz1010.

Falush D. 2016. Bacterial genomics: Microbial GWAS coming of age. Nature Microbiology 1. DOI: $10.1038 /$ nmicrobiol.2016.59.

Feldgarden M, Brover V, Haft DH, Prasad AB, Slotta DJ, Tolstoy I, Tyson GH, Zhao S, Hsu CH, McDermott PF, Tadesse DA, Morales C, Simmons M, Tillman G, Wasilenko J, Folster JP, Klimke W. 2019. Validating the AMRFinder Tool and Resistance Gene Database by Using Antimicrobial Resistance Genotype-Phenotype Correlations in a Collection of Isolates. Antimicrobial Agents and Chemotherapy 63. DOI: 10.1128/AAC.00483-19.

France MT, Mendes-Soares H, Forney LJ. 2016. Genomic comparisons of Lactobacillus crispatus and Lactobacillus iners reveal potential ecological drivers of community composition in the vagina. Applied and Environmental Microbiology 82:7063-7073. DOI: 10.1128/AEM.02385-16.

García-Villar N, Hernández-Cassou S, Saurina J. 2009. Determination of biogenic amines in wines by pre-column derivatization and high-performance liquid chromatography coupled to mass spectrometry. Journal of Chromatography A 1216:6387-6393. DOI:

10.1016/j.chroma.2009.07.029.

Guizelini D, Raittz RT, Cruz LM, Souza EM, Steffens MBR, Pedrosa FO. 2016. GFinisher: a new strategy to refine and finish bacterial genome assemblies. Scientific Reports 6:34963. DOI: $10.1038 /$ srep34963.

Gupta SK, Padmanabhan BR, Diene SM, Lopez-Rojas R, Kempf M, Landraud L, Rolain JM. 2014. ARG-annot, a new bioinformatic tool to discover antibiotic resistance genes in bacterial genomes. Antimicrobial Agents and Chemotherapy 58:212-220. DOI: 10.1128/AAC.01310-13.

Gurevich A, Saveliev V, Vyahhi N, Tesler G. 2013. QUAST: Quality assessment tool for genome assemblies. Bioinformatics 29:1072-1075. DOI: 10.1093/bioinformatics/btt086.

Happel AU, Kullin B, Gamieldien H, Wentzel N, Zauchenberger CZ, Jaspan HB, Dabee S, Barnabas SL, Jaumdally SZ, Dietrich J, Gray G, Bekker LG, Froissart R, Passmore JAS. 2020. Exploring potential of vaginal Lactobacillus isolates from South African women for enhancing treatment for bacterial vaginosis. PLoS Pathogens 16:1-26. DOI: 10.1371/journal.ppat.1008559.

Peer) reviewing PDF | (2020:11:55691:1:1:NEW 16 Feb 2021) 
755

756

757

758

759

760

761

762

763

764

765

766

767

768

769

770

771

772

773

774

775

776

777

778

779

780

781

782

783

784

785

786

787

788

789

790

791

792

793

794

van Heel AJ, de Jong A, Song C, Viel JH, Kok J, Kuipers OP. 2018. BAGEL4: a user-friendly web server to thoroughly mine RiPPs and bacteriocins. Nucleic Acids Research 46:W278W281. DOI: 10.1093/nar/gky383.

Hernandez D, Francois P, Farinelli L, Osteras M, Schrenzel J. 2008. De novo bacterial genome sequencing: Millions of very short reads assembled on a desktop computer. Genome Research 18:802-809. DOI: 10.1101/gr.072033.107.

Hongo JA, de Castro GM, Cintra LC, Zerlotini A, Lobo FP. 2015. POTION: an end-to-end pipeline for positive Darwinian selection detection in genome-scale data through phylogenetic comparison of protein-coding genes. BMC genomics 16:567. DOI: 10.1186/s12864-015-1765-0.

Huerta-Cepas J, Forslund K, Coelho LP, Szklarczyk D, Jensen LJ, Von Mering C, Bork P. 2017. Fast genome-wide functional annotation through orthology assignment by eggNOGmapper. Molecular Biology and Evolution 34:2115-2122. DOI: 10.1093/molbev/msx148.

Hynönen U, Palva A. 2013. Lactobacillus surface layer proteins: Structure, function and applications. Applied Microbiology and Biotechnology 97:5225-5243. DOI: 10.1007/s00253-013-4962-2.

Jaillard M, Lima L, Tournoud M, Mahé P, van Belkum A, Lacroix V, Jacob L. 2018. A fast and agnostic method for bacterial genome-wide association studies: Bridging the gap between k-mers and genetic events. PLoS Genetics 14:1-28. DOI: 10.1371/journal.pgen.1007758.

Jones P, Binns D, Chang H-Y, Fraser M, Li W, McAnulla C, McWilliam H, Maslen J, Mitchell A, Nuka G, Pesseat S, Quinn AF, Sangrador-Vegas A, Scheremetjew M, Yong S-Y, Lopez R, Hunter S. 2014. InterProScan 5: genome-scale protein function classification. Bioinformatics 30:1236-1240. DOI: 10.1093/bioinformatics/btu031.

Kanehisa M, Sato Y. 2020. KEGG Mapper for inferring cellular functions from protein sequences. Protein Science 29:28-35. DOI: 10.1002/pro.3711.

Kanehisa M, Sato Y, Morishima K. 2016. BlastKOALA and GhostKOALA: KEGG Tools for Functional Characterization of Genome and Metagenome Sequences. Journal of Molecular Biology 428:726-731. DOI: 10.1016/j.jmb.2015.11.006.

Katoh K, Kuma KI, Toh H, Miyata T. 2005. MAFFT version 5: Improvement in accuracy of multiple sequence alignment. Nucleic Acids Research 33:511-518. DOI: 10.1093/nar/gki198.

Langmead B, Salzberg SL. 2012. Fast gapped-read alignment with Bowtie 2. Nature Methods 9:357-359. DOI: 10.1038/nmeth.1923.

Larkin MA, Blackshields G, Brown NP, Chenna R, Mcgettigan PA, McWilliam H, Valentin F, Wallace IM, Wilm A, Lopez R, Thompson JD, Gibson TJ, Higgins DG. 2007. Clustal W and Clustal X version 2.0. Bioinformatics 23:2947-2948. DOI:

10.1093/bioinformatics/btm404.

Lees JA, Vehkala M, Välimäki N, Harris SR, Chewapreecha C, Croucher NJ, Marttinen P, Davies MR, Steer AC, Tong SYC, Honkela A, Parkhill J, Bentley SD, Corander J. 2016. Sequence element enrichment analysis to determine the genetic basis of bacterial 
795

796

797

798

799

800

801

802

803

804

805

806

807

808

809

810

811

812

813

814

815

816

817

818

819

820

821

822

823

824

825

826

827

828

829

830

831

832

833

834

phenotypes. Nature Communications 7. DOI: 10.1038/ncomms12797.

Letunic I, Bork P. 2019. Interactive Tree Of Life (iTOL) v4: recent updates and new developments. Nucleic Acids Research 47:W256-W259. DOI: 10.1093/nar/gkz239.

Li H, Handsaker B, Wysoker A, Fennell T, Ruan J, Homer N, Marth G, Abecasis G, Durbin R. 2009. The Sequence Alignment/Map format and SAMtools. Bioinformatics 25:2078-2079. DOI: 10.1093/bioinformatics/btp352.

Linares DM, Martĺn MC, Ladero V, Alvarez MA, Fernández M. 2011. Biogenic amines in dairy products. Critical Reviews in Food Science and Nutrition 51:691-703. DOI: 10.1080/10408398.2011.582813.

Liu B, Zheng D, Jin Q, Chen L, Yang J. 2019. VFDB 2019: a comparative pathogenomic platform with an interactive web interface. Nucleic Acids Research 47:D687-D692. DOI: 10.1093/nar/gky1080.

Maddison WP. 2000. Testing character correlation using pairwise comparisons on a phylogeny. Journal of Theoretical Biology 202:195-204. DOI: 10.1006/jtbi.1999.1050.

Marconi C, El-Zein M, Ravel J, Ma B, Lima MD, Carvalho NS, Alves RRF, Parada CMGL, Leite SHM, Giraldo PC, Gonçalves AK, Franco EL, Silva MG. 2020. Characterization of the vaginal microbiome in women of reproductive age from 5 Regions in Brazil. Sexually Transmitted Diseases 47:562-569. DOI: 10.1097/OLQ.0000000000001204.

Martinez RCR, Franceschini SA, Patta MC, Quintana SM, Nunes ÁC, Moreira JLS, Anukam KC, Reid G, De Martinis ECP. 2008. Analysis of vaginal lactobacilli from healthy and infected Brazilian women. Applied and Environmental Microbiology 74:4539-4542. DOI: 10.1128/AEM.00284-08.

Meier-Kolthoff JP, Göker M. 2019. TYGS is an automated high-throughput platform for stateof-the-art genome-based taxonomy. Nature Communications 10:2182. DOI: 10.1038/s41467-019-10210-3.

Melsted P, Halldórsson B V. 2014. KmerStream: streaming algorithms for k -mer abundance estimation. Bioinformatics 30:3541-3547. DOI: 10.1093/bioinformatics/btu713.

Nguyen L-T, Schmidt HA, von Haeseler A, Minh BQ. 2015. IQ-TREE: A Fast and Effective Stochastic Algorithm for Estimating Maximum-Likelihood Phylogenies. Molecular Biology and Evolution 32:268-274. DOI: 10.1093/molbev/msu300.

Ojala T, Kankainen M, Castro J, Cerca N, Edelman S, Westerlund-Wikström B, Paulin L, Holm L, Auvinen P. 2014. Comparative genomics of Lactobacillus crispatus suggests novel mechanisms for the competitive exclusion of Gardnerella vaginalis. BMC Genomics 15:121. DOI: $10.1186 / 1471-2164-15-1070$.

Pan M, Hidalgo-Cantabrana C, Barrangou R. 2020. Host and body site-specific adaptation of Lactobacillus crispatus genomes. NAR Genomics and Bioinformatics 2:1-14. DOI: 10.1093/nargab/lqaa001.

Pariza MW, Gillies KO, Kraak-Ripple SF, Leyer G, Smith AB. 2015. Determining the safety of microbial cultures for consumption by humans and animals. Regulatory Toxicology and Pharmacology 73:164-171. DOI: 10.1016/j.yrtph.2015.07.003. 
835 Petersen L, Bollback JP, Dimmic M, Hubisz M, Nielsen R. 2007. Genes under positive selection 836 in Escherichia coli. Genome Research 17:1336-1343. DOI: 10.1101/gr.6254707.

837 Petit RA, Read TD. 2020. Bactopia: a flexible pipeline for complete analysis of bacterial 838 genomes. bioRxiv:2020.02.28.969394. DOI: 10.1101/2020.02.28.969394.

839

Rahman A, Srivastava SS, Sneh A, Ahmed N, Krishnasastry M V. 2010. Molecular

840

841

842

843

844

845

846

847

848

849

850

851

852 characterization of tlyA gene product, Rv1694 of Mycobacterium tuberculosis: A nonconventional hemolysin and a ribosomal RNA methyl transferase. BMC Biochemistry 11:35. DOI: 10.1186/1471-2091-11-35.

Ravel J, Gajer P, Abdo Z, Schneider GM, Koenig SSK, McCulle SL, Karlebach S, Gorle R, Russell J, Tacket CO, Brotman RM, Davis CC, Ault K, Peralta L, Forney LJ. 2011. Vaginal microbiome of reproductive-age women. Proceedings of the National Academy of Sciences 108:4680-4687. DOI: 10.1073/pnas.1002611107.

Read TD, Massey RC. 2014. Characterizing the genetic basis of bacterial phenotypes using genome-wide association studies: A new direction for bacteriology. Genome Medicine 6:111. DOI: 10.1186/s13073-014-0109-z.

Del Rio B, Alvarez-Sieiro P, Redruello B, Martin MC, Fernandez M, Ladero V, Alvarez MA. 2018. Lactobacillus rossiae strain isolated from sourdough produces putrescine from

853 arginine article. Scientific Reports 8:1-10. DOI: 10.1038/s41598-018-22309-6.

Saber MM, Shapiro BJ. 2020. Benchmarking bacterial genome-wide association study methods using simulated genomes and phenotypes. Microbial Genomics 6. DOI: 10.1099/mgen.0.000337.

San JE, Baichoo S, Kanzi A, Moosa Y, Lessells R, Fonseca V, Mogaka J, Power R, de Oliveira

862

863

864

865

866

867

868

869

870

871

872

873 T. 2020. Current Affairs of Microbial Genome-Wide Association Studies: Approaches,

Romano A, Ladero V, Alvarez MA, Lucas PM. 2014. Putrescine production via the ornithine decarboxylation pathway improves the acid stress survival of Lactobacillus brevis and is part of a horizontally transferred acid resistance locus. International Journal of Food Microbiology 175:14-19. DOI: 10.1016/j.ijfoodmicro.2014.01.009. Bottlenecks and Analytical Pitfalls. Frontiers in Microbiology 10. DOI: 10.3389/fmicb.2019.03119.

Schubert M, Lindgreen S, Orlando L. 2016. AdapterRemoval v2: rapid adapter trimming, identification, and read merging. BMC Research Notes 9:88. DOI: 10.1186/s13104-0161900-2.

Seemann T. 2014. Prokka: rapid prokaryotic genome annotation. Bioinformatics 30:2068-2069. DOI: 10.1093/bioinformatics/btu153.

Seppey M, Manni M, Zdobnov EM. 2019. BUSCO: Assessing Genome Assembly and Annotation Completeness. In: Martin Kollmar ed. Gene Prediction. New York, NY: Humana Press, 227-245. DOI: 10.1007/978-1-4939-9173-0_14.

Sheppard SK, Didelot X, Meric G, Torralbo A, Jolley KA, Kelly DJ, Bentley SD, Maiden MCJ, Parkhill J, Falush D. 2013. Genome-wide association study identifies vitamin B5 874 biosynthesis as a host specificity factor in Campylobacter. Proceedings of the National 
875

876

877

878

879

880

881

882

883

884

885

886

887

888

889

890

891

892

893

894

895

896

897

898

899

900

901

902

903

904

905

906

907

908

909

910

911

912

913

914

Academy of Sciences of the United States of America 110:11923-11927. DOI: 10.1073/pnas.1305559110.

Siguier P, Gourbeyre E, Chandler M. 2014. Bacterial insertion sequences: Their genomic impact and diversity. FEMS Microbiology Reviews 38:865-891. DOI: 10.1111/1574-6976.12067.

Simpson JT, Wong K, Jackman SD, Schein JE, Jones SJM, Birol I. 2009. ABySS: A parallel assembler for short read sequence data. Genome Research 19:1117-1123. DOI: 10.1101/gr.089532.108.

Smith SB, Ravel J. 2017. The vaginal microbiota, host defence and reproductive physiology. Journal of Physiology 595:451-463. DOI: 10.1113/JP271694.

Tachedjian G, O'Hanlon DE, Ravel J. 2018. The implausible "in vivo" role of hydrogen peroxide as an antimicrobial factor produced by vaginal microbiota. Microbiome 6:3-7. DOI: 10.1186/s40168-018-0418-3.

Terai T, Kato K, Ishikawa E, Nakao M, Ito M, Miyazaki K, Kushiro A, Imai S, Nomura Y, Hanada N, Okumura T. 2020. Safety assessment of the Candidate oral probiotic Lactobacillus crispatus YIT 12319: Analysis of antibiotic resistance and virulenceassociated genes. Food and Chemical Toxicology 140:111278. DOI: 10.1016/j.fct.2020.111278.

Tytgat HLP, Lebeer S. 2014. The Sweet Tooth of Bacteria: Common Themes in Bacterial Glycoconjugates. Microbiology and Molecular Biology Reviews 78:372-417. DOI: 10.1128/MMBR.00007-14.

van der Veer C, Hertzberger RY, Bruisten SM, Tytgat HLP, Swanenburg J, de Kat AngelinoBart A, Schuren F, Molenaar D, Reid G, de Vries H, Kort R. 2019. Comparative genomics of human Lactobacillus crispatus isolates reveals genes for glycosylation and glycogen degradation: implications for in vivo dominance of the vaginal microbiota. Microbiome 7:49. DOI: 10.1186/s40168-019-0667-9.

Wick RR, Judd LM, Gorrie CL, Holt KE. 2017. Unicycler: Resolving bacterial genome assemblies from short and long sequencing reads. PLOS Computational Biology 13:e1005595. DOI: 10.1371/journal.pcbi.1005595.

Xie Z, Tang H. 2017. ISEScan: automated identification of insertion sequence elements in prokaryotic genomes. Bioinformatics 33:3340-3347. DOI: 10.1093/bioinformatics/btx433. Yang Z, Nielsen R. 2002. Codon-Substitution Models for Detecting Molecular Adaptation at Individual Sites Along Specific Lineages. Molecular Biology and Evolution 19:908-917. DOI: 10.1093/oxfordjournals.molbev.a004148.

Zafar H, Saier MH. 2020. Comparative Genomics of the Transport Proteins of Ten Lactobacillus Strains. Genes 11:1234. DOI: 10.3390/genes11101234.

Zhang Q, Zhang L, Ross P, Zhao J, Zhang H, Chen W. 2020. Comparative Genomics of Lactobacillus crispatus from the Gut and Vagina Reveals Genetic Diversity and Lifestyle Adaptation. Genes 11:360. DOI: 10.3390/genes11040360.

Zimin A V, Marçais G, Puiu D, Roberts M, Salzberg SL, Yorke JA. 2013. The MaSuRCA genome assembler. Bioinformatics 29:2669-2677. DOI: 10.1093/bioinformatics/btt476. 
Table $\mathbf{1}$ (on next page)

List of Lactobacillus crispatus genomes 


\begin{tabular}{|c|c|c|c|c|c|c|}
\hline Strain & Condition & Microbiome & Metadata & Country & GenBank & Reference \\
\hline RL02 & $\mathrm{BV}$ & DVM & BV-positive & Netherlands & NKLR01 & $\begin{array}{l}\text { (Dols et al., 2016; van der Veer et } \\
\text { al., 2019) }\end{array}$ \\
\hline RL07 & BV & DVM & BV-positive & Netherlands & NKLN01 & $\begin{array}{l}\text { (Dols et al., 2016; van der Veer et } \\
\text { al., 2019) }\end{array}$ \\
\hline RL13 & BV & DVM & BV-positive & Netherlands & NKLI01 & $\begin{array}{l}\text { (Dols et al., 2016; van der Veer et } \\
\text { al., 2019) }\end{array}$ \\
\hline RL14 & BV & DVM & BV-positive & Netherlands & NKLH01 & $\begin{array}{l}\text { (Dols et al., 2016; van der Veer et } \\
\text { al., 2019) }\end{array}$ \\
\hline RL15 & BV & DVM & BV-positive & Netherlands & NKLG01 & $\begin{array}{l}\text { (Dols et al., 2016; van der Veer et } \\
\text { al., 2019) }\end{array}$ \\
\hline RL17 & BV & DVM & BV-positive & Netherlands & NKLE01 & $\begin{array}{l}\text { (Dols et al., 2016; van der Veer et } \\
\text { al., 2019) }\end{array}$ \\
\hline RL19 & BV & DVM & BV-positive & Netherlands & NKLD01 & $\begin{array}{l}\text { (Dols et al., 2016; van der Veer et } \\
\text { al., 2019) }\end{array}$ \\
\hline RL20 & BV & DVM & BV-positive & Netherlands & NKLC01 & $\begin{array}{l}\text { (Dols et al., 2016; van der Veer et } \\
\text { al., 2019) }\end{array}$ \\
\hline RL21 & BV & DVM & BV-positive & Netherlands & NKLB01 & $\begin{array}{l}\text { (Dols et al., 2016; van der Veer et } \\
\text { al., 2019) }\end{array}$ \\
\hline RL23 & BV & DVM & BV-positive & Netherlands & NKLA01 & $\begin{array}{l}\text { (Dols et al., 2016; van der Veer et } \\
\text { al., 2019) }\end{array}$ \\
\hline RL24 & BV & DVM & BV-positive & Netherlands & NKKZ01 & $\begin{array}{l}\text { (Dols et al., 2016; van der Veer et } \\
\text { al., 2019) }\end{array}$ \\
\hline RL25 & BV & DVM & BV-positive & Netherlands & NKKY01 & $\begin{array}{l}\text { (Dols et al., 2016; van der Veer et } \\
\text { al., 2019) }\end{array}$ \\
\hline RL28 & $\mathrm{BV}$ & DVM & BV-positive & Netherlands & NKKV01 & $\begin{array}{l}\text { (Dols et al., 2016; van der Veer et } \\
\text { al., 2019) }\end{array}$ \\
\hline RL30 & $\mathrm{BV}$ & DVM & BV-positive & Netherlands & NKKT01 & $\begin{array}{l}\text { (Dols et al., 2016; van der Veer et } \\
\text { al., 2019) }\end{array}$ \\
\hline RL31 & BV & DVM & BV-positive & Netherlands & NKKS01 & $\begin{array}{l}\text { (Dols et al., 2016; van der Veer et } \\
\text { al., 2019) }\end{array}$ \\
\hline RL33 & BV & DVM & BV-positive & Netherlands & NKKQ01 & $\begin{array}{l}\text { (Dols et al., 2016; van der Veer et } \\
\text { al., 2019) }\end{array}$ \\
\hline VMC1 & BV & DVM & $\begin{array}{l}\text { History of BV. }<50 \% \text { lactobacilli and } \\
>50 \% \text { of BV-associated taxa }\end{array}$ & USA & LJCZ01 & (Abdelmaksoud et al., 2016) \\
\hline VMC2 & BV & DVM & $\begin{array}{l}\text { History of BV. }<50 \% \text { lactobacilli and } \\
>50 \% \text { of BV-associated taxa }\end{array}$ & USA & LJDA01 & (Abdelmaksoud et al., 2016) \\
\hline
\end{tabular}




\begin{tabular}{|c|c|c|c|c|c|c|}
\hline VMC3 & BV & DVM & $\begin{array}{l}\text { History of BV. }<50 \% \text { lactobacilli and } \\
>50 \% \text { of BV-associated taxa }\end{array}$ & USA & LJGP01 & (Abdelmaksoud et al., 2016) \\
\hline VMC4 & BV & DVM & $\begin{array}{l}\text { History of BV. } \sim 86 \% \text { L. crispatus and } \\
\sim 12 \% \text { BV-associated taxa }\end{array}$ & USA & LJGQ01 & (Abdelmaksoud et al., 2016) \\
\hline CRI4 & Healthy & - & Healthy & Brazil & JABERN01 & This study \\
\hline$\overline{\text { CRI8 }}$ & Healthy & - & Healthy & Brazil & JABERO01 & This study \\
\hline CRI10 & Healthy & - & Healthy & Brazil & JABERP01 & This study \\
\hline CRI17 & Healthy & - & Healthy & Brazil & JABERQ01 & This study \\
\hline 2029 & Healthy & - & Healthy, probiotic strain & Russia & AVFH01 & (Abramov et al., 2014) \\
\hline $\begin{array}{l}125-2- \\
\mathrm{CHN}\end{array}$ & Healthy & - & Healthy & China & ACPV01 & $\begin{array}{lcc}\text { (Ojala et al., } & \text { 2014), } \\
\text { www.beiresources.org } & \\
\end{array}$ \\
\hline AB70 & Healthy & - & Healthy & South Korea & $\begin{array}{l}\text { CP026503, } \\
\text { CP026504 }\end{array}$ & (Chang et al., 2019) \\
\hline $\begin{array}{l}\text { CIP } \\
104459\end{array}$ & Healthy & - & Healthy & France & VOMA01 & (Clabaut et al., 2020) \\
\hline CTV-05 & Healthy & - & Healthy, probiotic strain & - & ADML01 & $\begin{array}{l}\text { (Hemmerling et al., 2010; Ojala et } \\
\text { al., 2014) }\end{array}$ \\
\hline JV-V01 & Healthy & - & Normal human vaginal flora & - & ACKR01 & $\begin{array}{l}\text { (Witkin et al., 2013; Ojala et al., } \\
\text { 2014), www.beiresources.org }\end{array}$ \\
\hline $\begin{array}{l}\text { MV-1A- } \\
\text { US }\end{array}$ & Healthy & - & Healthy & USA & ACOG01 & $\begin{array}{l}\text { (Witkin et al., 2013; Ojala et al., } \\
\text { 2014), www.beiresources.org }\end{array}$ \\
\hline $\begin{array}{l}\text { MV-3A- } \\
\text { US }\end{array}$ & Healthy & - & Healthy & USA & ACQC01 & $\begin{array}{l}\text { (Witkin et al., 2013; Ojala et al., } \\
\text { 2014), www.beiresources.org }\end{array}$ \\
\hline RL03 & Healthy & LVM & BV-negative & Netherlands & NKLQ01 & $\begin{array}{l}\text { (Dols et al., 2016; van der Veer et } \\
\text { al., 2019) }\end{array}$ \\
\hline RL05 & Healthy & LVM & BV-negative & Netherlands & NKLP01 & $\begin{array}{l}\text { (Dols et al., 2016; van der Veer et } \\
\text { al., 2019) }\end{array}$ \\
\hline RL06 & Healthy & LVM & BV-negative & Netherlands & NKLO01 & $\begin{array}{l}\text { (Dols et al., 2016; van der Veer et } \\
\text { al., 2019) }\end{array}$ \\
\hline RL08 & Healthy & LVM & BV-negative & Netherlands & NKLM01 & $\begin{array}{l}\text { (Dols et al., 2016; van der Veer et } \\
\text { al., 2019) }\end{array}$ \\
\hline RL09 & Healthy & LVM & BV-negative & Netherlands & NKLL01 & $\begin{array}{l}\text { (Dols et al., 2016; van der Veer et } \\
\text { al., 2019) }\end{array}$ \\
\hline RL10 & Healthy & LVM & BV-negative & Netherlands & NKLK01 & $\begin{array}{l}\text { (Dols et al., 2016; van der Veer et } \\
\text { al., 2019) }\end{array}$ \\
\hline RL11 & Healthy & LVM & BV-negative & Netherlands & NKLJ01 & $\begin{array}{l}\text { (Dols et al., 2016; van der Veer et } \\
\text { al., 2019) }\end{array}$ \\
\hline RL16 & Healthy & LVM & BV-negative & Netherlands & NKLF01 & (Dols et al., 2016; van der Veer et \\
\hline
\end{tabular}




\begin{tabular}{|l|l|l|l|l|l|l|}
\hline RL26 & Healthy & LVM & BV-negative & Netherlands & NKKX01 & $\begin{array}{l}\text { al., 2019) } \\
\text { (Dols et al., 2019) }\end{array}$ \\
\hline RL27 & Healthy & LVM & BV-negative & Netherlands & NKKW01 & $\begin{array}{l}\text { (Dols et al., 2016; van der Veer et } \\
\text { al., 2019) }\end{array}$ \\
\hline RL29 & Healthy & LVM & BV-negative & Netherlands & NKKU01 & $\begin{array}{l}\text { (Dols et al., 2016; van der Veer et } \\
\text { al., 2019) }\end{array}$ \\
\hline RL32 & Healthy & LVM & BV-negative & Netherlands & NKKR01 & $\begin{array}{l}\text { (Dols et al., 2016; van der Veer et } \\
\text { al., 2019) }\end{array}$ \\
\hline SJ-3C-US & Healthy & - & Healthy & Iran & ADDT01 & (Eslami et al., 2016) \\
\hline V4 & Healthy & - & Healthy & France & SRLG01 & (Clabaut et al., 2019) \\
\hline VMC5 & Healthy & LVM & $\begin{array}{l}\text { No history of BV. }>90 \% \text { L. crispatus } \\
\text { and }<10 \% \text { BV-associated bacterial taxa }\end{array}$ & USA & LJOK01 & (Abdelmaksoud et al., 2016) \\
\hline VMC6 & Healthy & LVM & $\begin{array}{l}\text { No history of BV. Dominated by L. } \\
\text { crispatus and L. jensenii }\end{array}$ & USA & LJOL01 & (Abdelmaksoud et al., 2016) \\
\hline VMC7 & Healthy & LVM & $\begin{array}{l}\text { No history of BV. }>90 \% \text { L. crispatus } \\
\text { and }<10 \% \text { BV-associated bacterial taxa }\end{array}$ & USA & LJOM01 & (Abdelmaksoud et al., 2016) \\
\hline VMC8 & Healthy & LVM & $\begin{array}{l}\text { No history of BV. >90 \% L. crispatus } \\
\text { and }<10 \% \text { BV-associated bacterial taxa }\end{array}$ & USA & LJON01 & (Abdelmaksoud et al., 2016) \\
\hline
\end{tabular}




\section{Table 2 (on next page)}

Statistics of genome sequencing, assembly, and annotation of the Lactobacillus crispatus strains CRI4, CRI8, CRI10, and CRI17. 
1

\begin{tabular}{|l|r|r|r|r|}
\hline & CRI4 & CRI8 & CRI10 & CRI17 \\
\hline SRA accession & SRR13201099 & SRR13201098 & SRR13201097 & SRR13201096 \\
\hline Replicon accession & JABERN01 & JABERO01 & JABERP01 & JABERQ01 \\
\hline Completeness & $99.5 \%$ & $99.2 \%$ & $99.0 \%$ & $99.0 \%$ \\
\hline Size $(\mathrm{bp})$ & $2,376,268$ & $2,330,310$ & $2,418,420$ & $2,384,332$ \\
\hline Contig & 100 & 65 & 65 & 79 \\
\hline N50 $(\mathrm{bp})$ & 44.691 & 69.313 & 75.243 & 58.032 \\
\hline L50 & 19 & 10 & 11 & 14 \\
\hline CDS & 2.438 & 2.329 & 2.478 & 2.393 \\
\hline Plasmid & None & None & None & None \\
\hline
\end{tabular}

2 


\section{Table 3 (on next page)}

Genomic features related to probiotic effects in Lactobacillus crispatus strains CRI4, CRI8, CRI10 and CR17. 


\begin{tabular}{|c|c|c|c|c|c|c|c|}
\hline \multirow[b]{2}{*}{ Feature } & \multirow[b]{2}{*}{ Product (Gene) } & \multirow[b]{2}{*}{ KEGG ID } & \multirow[b]{2}{*}{ Protein ID } & \multicolumn{4}{|c|}{ Strain } \\
\hline & & & & CRI4 & CRI8 & CRI10 & CRI17 \\
\hline \multicolumn{8}{|c|}{$\begin{array}{l}\text { Lactic acid } \\
\text { synthesis }\end{array}$} \\
\hline & D-lactate & & & 1 & 1 & 1 & 1 \\
\hline & $\begin{array}{l}\text { D-lactate dehydrogenase } \\
\text { [EC:1.1.1.28] }(l d h A)\end{array}$ & K03778 & WP_005720611 & 1 & 1 & 1 & 1 \\
\hline & L-lactate & & & 3 & 3 & 3 & 3 \\
\hline & $\begin{array}{l}\text { L-lactate dehydrogenase } \\
{[\mathrm{EC}: 1.1 .1 .27](l d h)}\end{array}$ & K00016 & WP_005721100 & 1 & 1 & 1 & 1 \\
\hline & & K00016 & WP_005720302 & 1 & WP_170080485 & 1 & WP_005721074 \\
\hline & $\begin{array}{l}\text { L-2-hydroxyisocaproate } \\
\text { dehydrogenase }(\text { hicDH })\end{array}$ & K00016 & WP_005727148 & WP_005719855 & 1 & 1 & 1 \\
\hline \multicolumn{8}{|c|}{ Bacteriocin } \\
\hline & Class: 210.2 ; SakT_alpha & & & 2 & 2 & 3 & 2 \\
\hline & $\begin{array}{l}\text { ggmotif; ComC; } \\
\text { Bacteriocin_IIc; }\end{array}$ & - & WP_005721006 & 1 & 1 & 1 & 1 \\
\hline & $\begin{array}{l}\text { ComC; L_biotic_typeA; } \\
\text { Bacteriocin_IIc; } 20.2 ; \\
\text { bacteriocin_LS2chaina }\end{array}$ & & WP_005721005 & 1 & 1 & 1 & 1 \\
\hline & $\begin{array}{l}\text { ComC; L_biotic_typeA; } \\
\text { Bacteriocin_IIc; }\end{array}$ & - & WP_005720990 & - & - & 1 & - \\
\hline & Class: 70.3; Helveticin-J & & & 1 & 2 & 2 & 2 \\
\hline & 70.3; Helveticin-J & - & WP_005729773 & - & 1 & 1 & 1 \\
\hline & & - & WP_005720754 & 1 & 1 & 1 & 1 \\
\hline & $\begin{array}{l}\text { Class: } 64.3 ; \\
\text { Enterolysin A }\end{array}$ & & & 1 & 2 & 2 & 2 \\
\hline & 64.3; Enterolysin_A & - & WP_005728076 & - & 1 & 1 & 1 \\
\hline & & - & WP_005719715 & 1 & 1 & 1 & 1 \\
\hline & Class: 163.2; Penocin_A & & & - & - & 2 & 1 \\
\hline & $\begin{array}{l}\text { bacteriocinII; } \\
\text { Bacteriocin II; ComC; }\end{array}$ & - & WP_005723822 & - & - & 1 & 1 \\
\hline
\end{tabular}




\begin{tabular}{|c|c|c|c|c|c|c|c|}
\hline & $\begin{array}{l}\text { Bacteriocin_IIc; } 163.2 ; \\
\text { Penocin_A }\end{array}$ & & & & & & \\
\hline & Bacteriocin_IIc; & - & WP_005727428 & - & - & 1 & - \\
\hline & $\begin{array}{l}\text { Class: } 6.3 \text {; } \\
\text { Bacteriocin_helveticin_J }\end{array}$ & & & 1 & 1 & 1 & 1 \\
\hline & $\begin{array}{l}6.3 \text {; } \\
\text { Bacteriocin helveticin } \mathrm{J}\end{array}$ & - & WP_005728268 & WP_005718134 & 1 & 1 & 1 \\
\hline & Class: LAPs & & & - & - & 1 & - \\
\hline & $\begin{array}{l}\text { Putative nitroreductase } \\
\text { MJ1384 }\end{array}$ & - & WP_005721909 & - & - & 1 & - \\
\hline \multicolumn{8}{|l|}{$\begin{array}{l}\text { Hydrogen } \\
\text { peroxide } \\
\text { synthesis }\end{array}$} \\
\hline & $\begin{array}{l}\text { Pyruvate oxidase } \\
\text { [EC:1.2.3.3] (poxL) }\end{array}$ & K00158 & WP_005723618 & 1 & 1 & 1 & 1 \\
\hline \multicolumn{8}{|l|}{ Adhesin } \\
\hline & Putative adhesin & & WP_005728236 & 1 & 1 & 1 & 1 \\
\hline & & & WP_005729490 & - & 1 & 1 & 1 \\
\hline $\begin{array}{l}\text { Antimicrobial } \\
\text { production }\end{array}$ & - & - & - & - & - & - & - \\
\hline
\end{tabular}




\section{Table 4 (on next page)}

Genomic features related to safety in Lactobacillus crispatus strains CRI4, CRI8, CRI10, and CR17. 


\begin{tabular}{|c|c|c|c|c|c|c|c|}
\hline \multirow[b]{2}{*}{ Feature } & \multirow[b]{2}{*}{ Product (Gene) } & \multirow[b]{2}{*}{ KEGG ID } & \multirow[b]{2}{*}{ BLASTp hit } & \multicolumn{4}{|c|}{ Strain } \\
\hline & & & & CRI4 & CRI8 & CRI10 & CRI17 \\
\hline \multicolumn{8}{|c|}{ Mobile elements } \\
\hline Plasmid & & & & - & - & - & - \\
\hline $\begin{array}{l}\text { Insertion } \\
\text { sequences }\end{array}$ & & & & 131 & 171 & 178 & 184 \\
\hline Prophages & & & & $\begin{array}{c}\quad 2 \\
\text { questionable, } \\
4 \text { incomplete }\end{array}$ & $\begin{array}{c}5 \\
\text { incomplete }\end{array}$ & $\begin{array}{l}1 \\
1 \\
\text { questionable, } \\
5 \text { incomplete }\end{array}$ & $\begin{array}{c}1 \\
\text { questionable, } \\
4 \text { incomplete }\end{array}$ \\
\hline $\begin{array}{l}\text { CRISPR-Cas } \\
\text { system }\end{array}$ & & & & $\begin{array}{l}\text { CAS- } \\
\text { TypeIIA }\end{array}$ & $\begin{array}{l}\text { CAS- } \\
\text { TypeIIA }\end{array}$ & $\begin{array}{c}\text { CAS- } \\
\text { TypeIIA, } \\
\text { CAS-TypeIIC }\end{array}$ & CAS-TypeIIA \\
\hline \multicolumn{8}{|c|}{ Bacterial toxins } \\
\hline & Hemolysin A $($ tly $A)$ & K06442 & WP_005723149 & - & 1 & 1 & 1 \\
\hline & $\begin{array}{l}\text { Putative hemolysin } \\
(\operatorname{tly} C)\end{array}$ & K03699 & WP_005727867 & 1 & 1 & 1 & 1 \\
\hline & $\begin{array}{l}\text { Hemolysin-III related } \\
(\text { hlyIII) }\end{array}$ & K11068 & WP_005720215 & 1 & 1 & 1 & 1 \\
\hline \multicolumn{8}{|l|}{$\begin{array}{l}\text { Bile salt } \\
\text { deconjugation }\end{array}$} \\
\hline & $\begin{array}{l}\text { Choloylglycine } \\
\text { hydrolase/bile salt } \\
\text { hydrolase }(c b h)\end{array}$ & K01442 & WP_005718943 & 1 & 1 & 1 & 1 \\
\hline \multicolumn{8}{|c|}{$\begin{array}{l}\text { Biogenic amine } \\
\text { formation }\end{array}$} \\
\hline & $\begin{array}{l}\text { Ornithine decarboxylase } \\
(\text { odcl })\end{array}$ & K01581 & WP_005727730 & 1 & 1 & 1 & 1 \\
\hline
\end{tabular}


Antimicrobia resistance 


\section{Table 5 (on next page)}

Genes under positive selection in Lactobacillus crispatus genomes from healthy and bacterial vaginosis samples.

PS - positively selected sites. 
1

\begin{tabular}{lllllll}
\hline Product (Gene) & COG & Location & Sequences/genomes & PS sites & Positions & Protein ID \\
\hline $\begin{array}{l}\text { Integrase core domain } \\
\text { protein }\end{array}$ & $\mathrm{L}$ & CYTOPLASMIC & $53 / 50$ & 1 & 160 & EKB63650 \\
$\begin{array}{l}\text { S-layer protein } \\
\text { precursor }\end{array}$ & $\mathrm{S}$ & SECRETED & $42 / 50$ & 1 & 130 & EKB61518 \\
$\begin{array}{l}\text { Hypothetical protein } \\
\text { - }\end{array}$ & & CYTOPLASMIC & $15 / 50$ & 11 & $31,39,49,48,52$, & WP_126708926 \\
& & & & $58,94,95,103$, & 107,126 & WP_133463822 \\
$\begin{array}{l}\text { ORF6N domain protein } \\
\begin{array}{l}\text { Tyrosine recombinase } \\
\text { XerS }(x e r S)\end{array}\end{array}$ & $\mathrm{K}$ & CYTOPLASMIC & $10 / 50$ & 2 & 240,256 & WP_133475995 \\
\hline
\end{tabular}


Figure 1

Insertion sequence from IS607-like family located in two prophages (regions) in Lactobacillus crispatus strain CRI8.

(A) Region 2 and (B) Region 3. The insertion sequences from the IS607-like family are two subsequent transposases, located in region 2 and at the end of region 3. Att - Attachment Site, Coa - Coat protein (Purple), Hyp - Hypothetical protein (Green), Int - Integrase (Blue), Pla - Plate protein (Orange), PLP - Phage-like Protein (Cyan), Tra - Transposase (Olive).

A

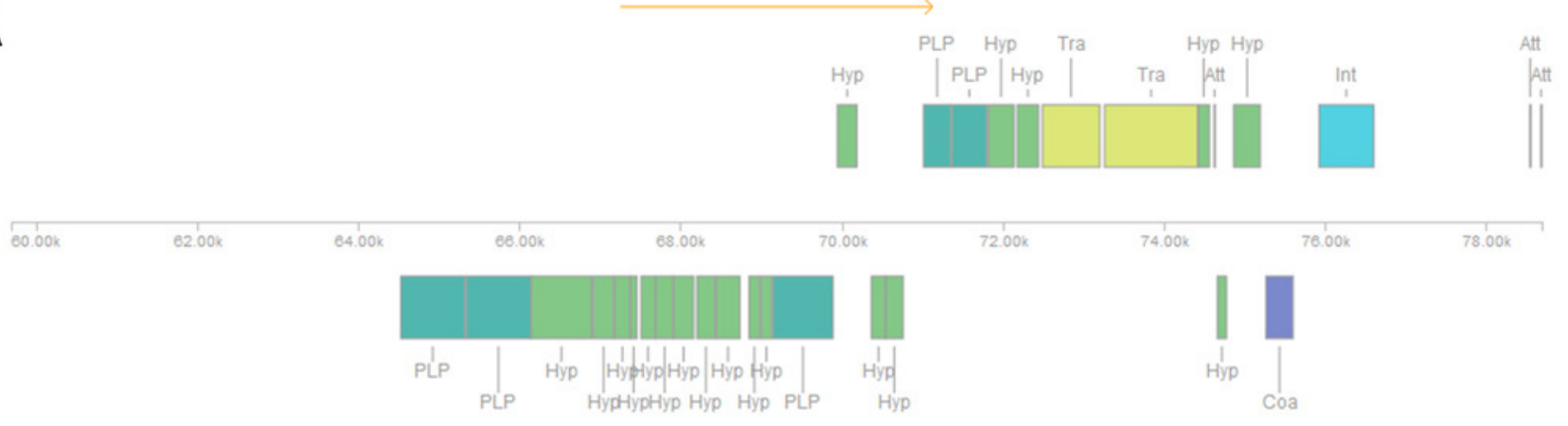

B

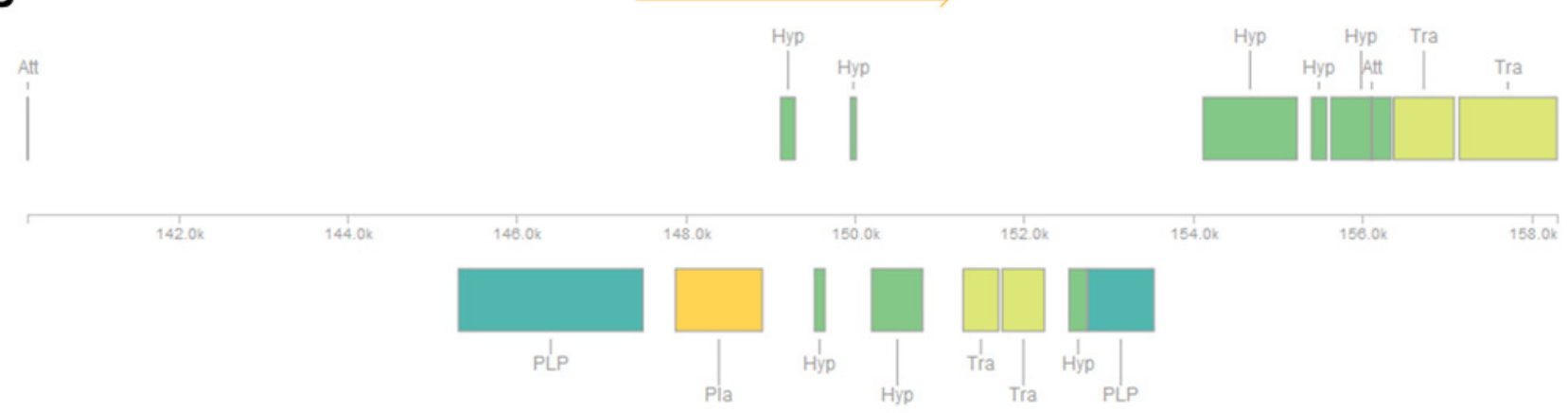


Figure 2

CRISPR-Cas systems subtype II-A predicted in four Lactobacillus crispatus strains from Brazil.

(A) Strain CRI4, (B) CRI8, (C) CRI10 and (D) CR17. The genes csn2 and cas9 are fragmented in the four genomes. Colors of the protein coding sequences green - csn2, cas2 and cas1; red - cas9 fragments; pink - transposase.

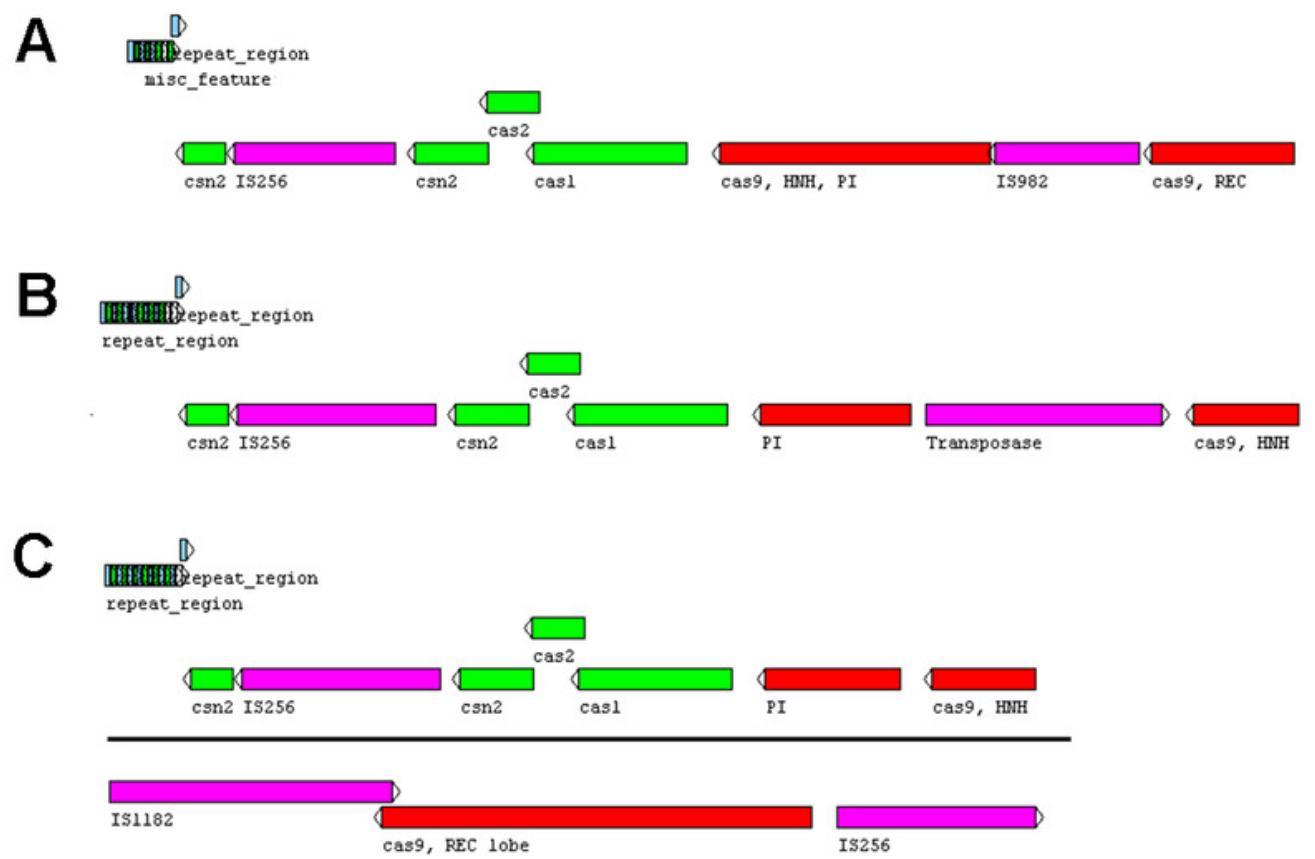

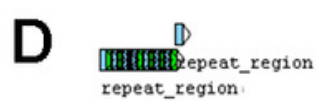
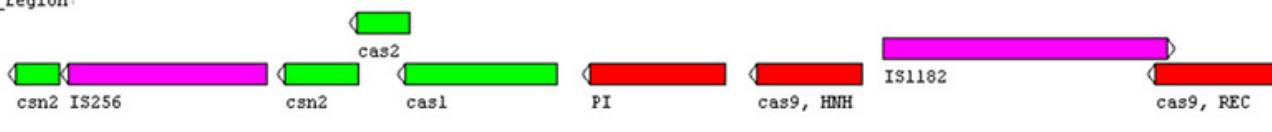


\section{Figure 3}

Transmission electron microscopy of the strain CRI4 filtrate.

(A) Presence of stick-shaped structures. (B) Structure similar to a capsid with contractile tail (Myoviridae).
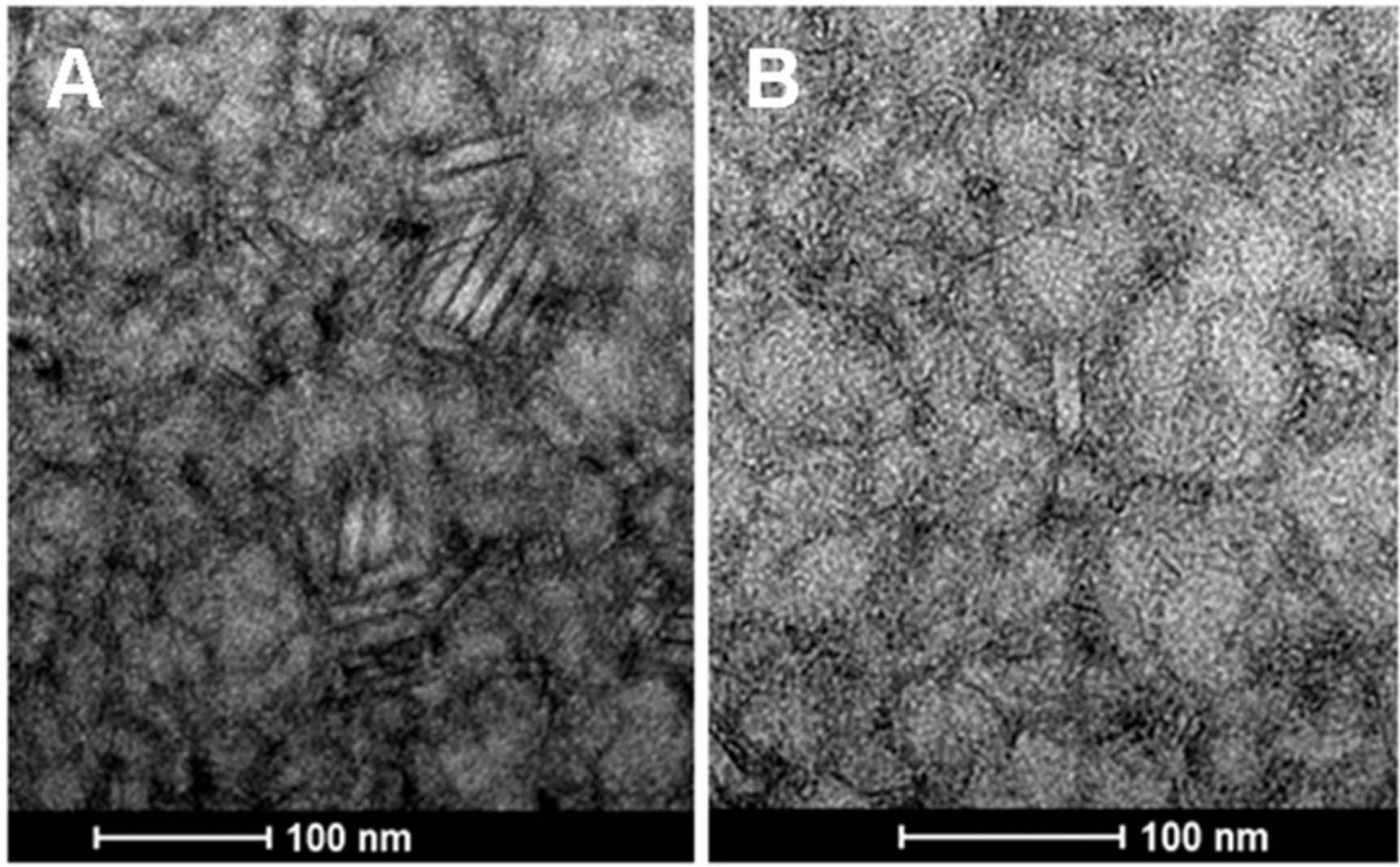
Figure 4

Phylogenomic tree of Lactobacillus crispatus strains from vaginal isolates.

The tree was built using the nucleotide sequences of 118 core genes predicted by Roary and aligned by MAFFT, 1,000 rounds of bootstrapping, and Maximum Likelihood phylogenetic inference implemented in IQ-TREE. Filled squares - bacterial vaginosis samples, Empty squares - samples from healthy individuals. 


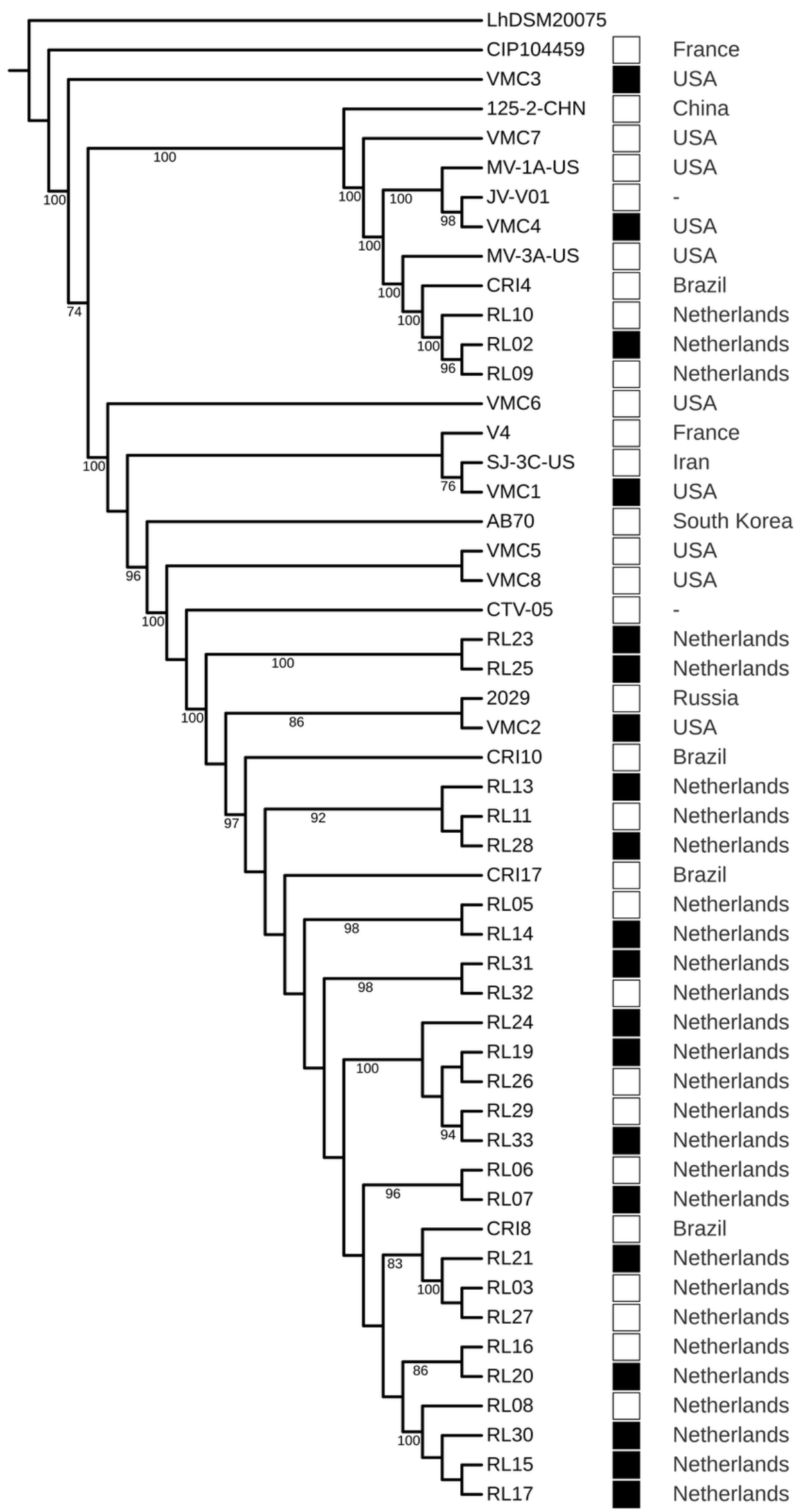

